\title{
Source-to-sink analysis of continental rift sedimentation: Triassic Cuyo basin, Precordillera Argentina
}

\author{
Bárbara M.N. Teixeira ${ }^{\mathrm{a}, *}$, Ricardo A. Astini ${ }^{\mathrm{b}}$, Fernando J. Gomez ${ }^{\mathrm{b}}$, Norberto Morales ${ }^{\mathrm{c}}$, Márcio M. Pimentel ${ }^{\mathrm{d}}$ \\ a Petrobras - Petróleo Brasileiro S.A., Avenida Chile, 65, Rio de Janeiro, RJ, Brazil \\ ${ }^{\mathrm{b}}$ Centro de Investigaciones en Ciencias de la Tierra, Universidad Nácional de Córdoba, Córdoba, Argentina \\ ${ }^{\mathrm{c}}$ Instituto de Geociências e Ciências Exatas, UNESP - Universidade Estadual Paulista, Rio Claro, SP, Brazil \\ d Instituto de Geociências, Universidade de Brasília, Brasília, DF, Brazil
}

\section{A R T I C L E I N F O}

\section{Article history:}

Received 5 March 2018

Received in revised form 14 August 2018

Accepted 15 August 2018

Available online 18 August 2018

Editor: Dr. J. Knight

\section{Keywords:}

Triassic

Cuyo basin

Rifting

Source-to-sink

Provenance

\begin{abstract}
A B S T R A C T
The northernmost outcrops of the Triassic extensional Cuyo basin in western Argentina reveal a basal coarse conglomerate overlain by a thinning-fining upward siliciclastic red-bedded section with subordinated tuffs and microbial-rich carbonates (Cerro Puntudo Formation), unconformably covered by a second coarse conglomerate (El Relincho Formation), which were previously interpreted as two rifting events. An integrated analysis of facies associations, stacking patterns, paleocurrent and provenance was carried out in order to reveal the rift sedimentation using a source-to-sink approach. Besides the traditional controls in continental basins (e.g., sedimentation, tectonics and climate), this study considers possible drainage pattern evolution in order to differentiate isolated versus integrated depocenter stages. U-Pb zircon data corroborate our analysis and reveal a volcanic basement source of $256.8 \pm 3.5 \mathrm{Ma}$ (Permian/Lopingian) and a sedimentation age of $249.8 \pm 2.5 \mathrm{Ma}$ (Early Triassic) for a tuff interbedded within the Cerro Puntudo Formation, complementing previous age of $243.8 \pm 1.9 \mathrm{Ma}$ (Middle Triassic) at the top of this unit. Stratigraphic stacking allows the interpretation of three evolutionary stages. A first stage, represented by thick massive boulder-volcanic-rich conglomerates characterizing alluvial fan deposition, indicates strong tectonic activity of border faults (first rifting event). These features suggest high surface gradient and high available space controlling accommodation and dispersal of gravity and debris-flow deposits. Paleocurrents to the east reveal largely north-south normal faults located to the west and sediment supply from a proximal volcanic source area. A second stage, represented by a notable fining-thinning upward facies, including fluvial and palustrine (stromatolites with pedogenetic features) deposits, indicates a transition to tectonic quiescence. These facies associations developed in a context of low sedimentation rate, limited tectonic relief and low accommodation space. A third stage is represented by greenish well-rounded coarse-grained polymictic conglomerates of El Relincho Formation that unconformably truncate the Cerro Puntudo Formation. These conglomerates are interpreted as perennial braided fluvial systems (with paleocurrents to the northwest) indicating drainage reorganization primarily influenced by climate change and combined tectonic reactivation, previously considered the second rifting event. Climate change affected sediment delivery and allowed regionally connectivity and overfilling of the depocenters. In this last stage, northwest axial transport from variable sources within the Precordillera (to the southeast) is inferred from provenance analysis indicating open linkeddepocenters. This study suggests a new stratigraphic correlation for the northern part of the Cuyo basin, implying that during the first rifting event a semi-arid climate prevailed with development of isolated and independent depocenters (first and second stages), whereas above the unconformity initiating the second rifting event (third stage) depocenters were interconnected. In the light of our source-to-sink analysis, such paleogeographic change allowed overfilling and laterally linkage of separate half-grabens along the Cuyo basin. Whereas tectonic reactivation may better explain renewed conglomerate deposition, climate change toward more humid conditions allowed previously separated depocenters to be connected through axial drainages.
\end{abstract}

(c) 2018 Elsevier B.V. All rights reserved.

\footnotetext{
* Corresponding author.

E-mail addresses: barbara.nascimento@petrobras.com.br (B.M.N. Teixeira), ricardo.astini@unc.edu.ar (R.A. Astini), fjgomez@unc.edu.ar (F.J. Gomez), nmorales@rc.unesp.br (N. Morales).
}

\section{Introduction}

Traditional work dealing with the study of continental rift basins and linked graben evolution typically focuses on structural framework and facies trends filling accommodation space (Lambiase and Morley, 
1999; Gawthorpe and Leeder, 2000; Martins-Neto and Catuneanu, 2010). Furthermore, a source-to-sink approach (Allen, 2008; Armitage et al., 2011; Smith et al., 2013) has changed our way of visualizing basin evolution and stratigraphic fill through the understanding of drainage patterns and the role of climate change, which are two variables that are not strictly related. Together with the more traditional controls, it may allow further understanding of continental rifts and their infilling.

Triassic rift basins in west Argentina, along the Andes and its foreland, have long been known for their oil importance (Kokogián and Mancilla, 1989; Zencich et al., 2008). From a historical viewpoint, they help understand the evolution of the western margin of Gondwana during its breakup (Uliana and Biddle, 1988; Ramos and Kay, 1991; Charrier et al., 2007). Although limited work has been published on the stratigraphy and paleoenvironments within this back-arc trending rifts (Kokogián and Mancilla, 1989; Kokogián et al., 1993; LópezGamundí and Astini, 2004; Barredo and Ramos, 2010), paleontological work (Spalletti, 1999; Stipanicic, 2002; Benavente et al., 2012) and recent radiometric dating (Ávila et al., 2006; Spalletti et al., 2008; Mancuso et al., 2010; Barredo et al., 2012) have allowed reasonable time-space framework and stratigraphic correlations to be carried out (Spalletti, 1999; Benavente et al., 2015).

In the frame of extensional basins, recent work has outlined the importance of time-constrained drainage pattern evolution as features that control the nature and composition of the stratigraphic fill. Rift basins can evolve from compartmentalized stages (separate grabens/ half-grabens with local base level) into non-compartmentalized stages with linked depocenters associated with a regional base level and open drainage patterns. Thus, it seems important to consider 3D and $4 \mathrm{D}$ evolution of paleocurrents as well as sediment composition in order to unravel connectivity through the basin fill.

In this study, we show how in a geochronologically constrained framework, through systematic facies analysis, provenance and paleocurrent measurements, we can discriminate stages of truly distinct and isolated depocenters from stages with signatures indicating linked systems within the Triassic extensional basins. This in turn may allow discussing stacking patterns, tectonic framework and basin evolution encompassing not only tectonics but also climate change and evolution of drainage patterns. This paper shows the data and interpretation reached through a source-to-sink approach in contrast to more traditional integrated tectonostratigraphic work.

\section{Geological setting}

The Triassic sediments of Cuyo basin belong to the western Precordillera geologic province, which is a thrust and fold belt located east of the southern Central Andes, formed during the Cenozoic Andes Orogeny (Charrier et al., 2007) (Fig. 1). This province had a complex evolution of accreted terranes at the margins of southern Gondwana from the Lower Ordovician to Lower Devonian (Ramos, 1994; Astini and Thomas, 1999). During the neo-Permian to neo-Triassic an extensional regime prevailed and resulted in a swarm of en echelon grabens, oriented NNW-SSE, in the South American continent, encompassing Chile and west of Argentina (Uliana and Biddle, 1988; Charrier et al., 2007; Giambiagi et al., 2011).

The Triassic troughs are related to the Choiyoi magmatic province of neo-Permian to eo-Triassic age, which outcrops in Frontal Cordillera and Western Precordillera (Fig. 1). Volcanic and volcaniclastic rocks of this province occur as basement or interbedded in the Triassic sediments (Uliana and Biddle, 1988; Ramos and Kay, 1991). Granitoids of the magmatic province have a post-collisional character (Mpodozis and Kay, 1992), which indicates that the extensional regime originated from a gravitational collapse (Uliana and Biddle, 1988; Mpodozis and Kay, 1992; Spalletti, 1999).

In Argentina, the extension was not enough to connect the Triassic grabens to the sea, hence the Cuyo basin is dominated by continental sedimentation (Stipanicic, 2002). It is considered the largest Triassic graben system of Argentina, with $30.000 \mathrm{~km}^{2}$ along Mendoza and San Juan provinces (Zencich et al., 2008). At least seven sub-basins have been recognized (Stipanicic, 2002), limited by master faults with opposite polarities (Criado Roqué et al., 1981), typical of rift environments. The depocenters are detached from each other by transfer zones (Ramos and Kay, 1991; Barredo, 2012).

The Tupungato depocenter is over $3500 \mathrm{~m}$ deep, located in the Mendoza region (Fig. 1) and has hydrocarbon accumulations that promoted the acquisition of seismic and well data (Kokogián and Mancilla, 1989; Zencich et al., 2008). A master fault located to the west and dipping to the east borders the Tupungato depocenter. In the San Juan region to the north, the Rincón Blanco depocenter is partially exposed in outcrops which reveal a master fault located to the east and dipping to the west, with a maximum infilling thickness of 3000 m (Barredo and Ramos, 2010). Previous studies suggest sediment infilling reaching 1800 m thickness toward Rincón Blanco flexural margin to the west (López-Gamundí and Astini, 1992). This depocenter is the nearest known to the study area.

\subsection{Study area}

The outcrops of Cerro Puntudo area (Lat: $30^{\circ} 55^{\prime} 49.60^{\prime \prime}$, Long: $69^{\circ} 16^{\prime} 55.77^{\prime \prime} \mathrm{W}$ ) are located west of San Juan Province, western Argentina, $62 \mathrm{~km}$ from the town of Calingasta. They are the northernmost part of Cuyo basin, $50 \mathrm{~km}$ from the Rincón Blanco depocenter (Fig. 1). The Triassic sediments of this region occur to the east of Cerro Puntudo hill where they are bordered by inverse faults located to the east/northeast and to the west/northwest. These faults, related to the Andes compressive tectonics (Figs. 1,2), are oriented N-NE and dip to the west, resulting in low angle strata dipping $\left(15-25^{\circ}\right)$ to the west.

Ordovician sedimentary/metamorphic rocks outcrop in Sierra del Tigre ridge (Cardó and Dias, 2005), located to the east/southeast of the Triassic sediments. Similar Ordovician deposits (sandstones) are exposed as basement of the Triassic units in the northeast of the study area. They occur in the core of an open anticline associated with the eastern inverse fault (Figs. 1, 2). Devonian sedimentary rocks are in tectonic contact (Sessarego, 1988) with Triassic sediments to the north and west, near Cerro Puntudo hill (Fig. 1). They occur as basement of the Triassic sediments in the northernmost part of the studied area, also related to the eastern open anticline (Fig. 2). On a regional scale, Devonian and Carboniferous sedimentary rocks also outcrop to the south/southeast in the San Juan river region (Fig. 1). An angular unconformity separates the Permian-Triassic andesite rocks of the Choiyoi Group from the Triassic sediments to the south (Sessarego, 1988) which are exposed by open anticline (Fig. 2). In this region, younger Triassic strata occur directly in contact with the volcanic basement, suggesting an onlap over the basement (Fig. 3).

In summary, the western Precordillera basement of Cuyo basin in the study area is composed of Ordovician low grade metamorphic rocks and Carboniferous/Devonian sedimentary rocks in the east/southeast, Devonian sedimentary rocks in the north and west, and PermianTriassic acid volcanic rocks in the south (Figs. 1, 2).

\subsection{Stratigraphy}

The Triassic lithostratigraphic sections of the Cerro Puntudo region (Figs. 3, 4) are composed of Cerro Puntudo and El Relincho Formations (Mombrú, 1974; Stipanicic, 2002), which are separated by an erosive unconformity (Mombrú, 1974; Sessarego, 1988). The section has an exposed thickness of approximately $400 \mathrm{~m}$ (Sessarego, 1988; LópezGamundí and Astini, 2004). To the north, the basal section of the Cerro Puntudo Formation overlays the Ordovician basement through an angular unconformity of $35^{\circ}$. It reaches a maximum thickness of $176 \mathrm{~m}$ and is pinkish in color (Fig. 4, section B). The upper reddish section is up to $138 \mathrm{~m}$ thick (Fig. 4, section C), although part of the section may be 


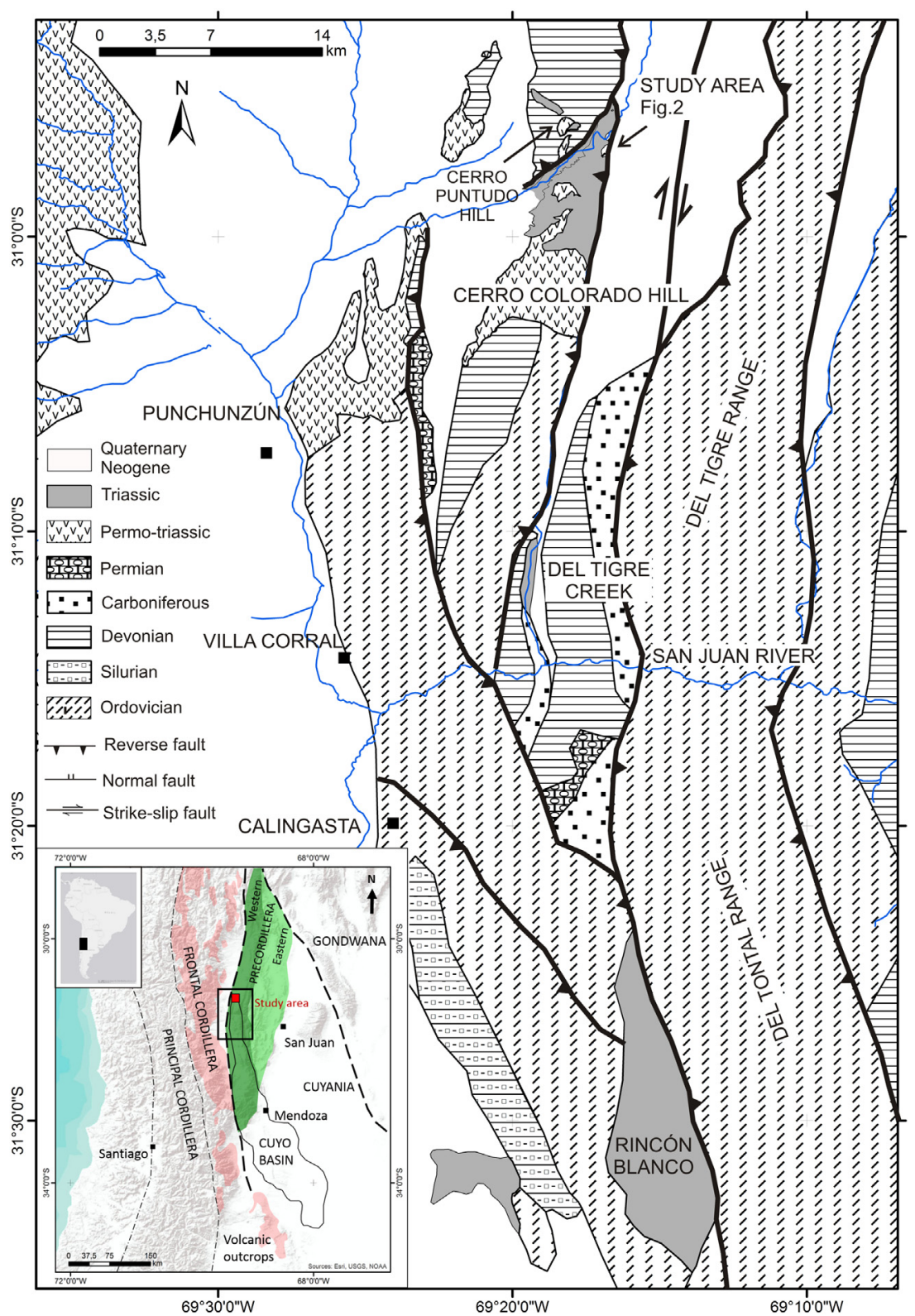

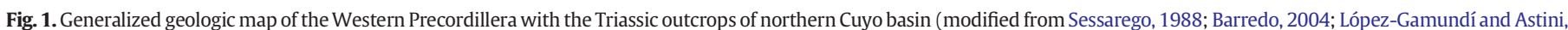

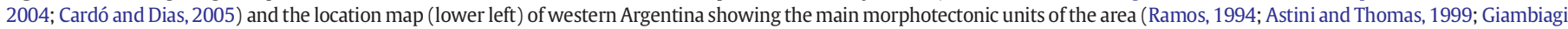
et al., 2011).

absent due to the erosive unconformity. The topmost El Relincho Formation is a greenish unit $60 \mathrm{~m}$ thick truncated by a reverse fault (Fig. 4, section C). Based on lithofacies, floral remains and stacking analysis, the sediments of the Cerro Puntudo area were originally correlated to other Triassic units of the Cuyo basin (Strelkov and Alvarez, 1984; Sessarego, 1988; López-Gamundí and Astini, 2004). An isotopic igneous age of $243.8 \pm 1.9 \mathrm{Ma}$ (Mancuso et al., 2010) in a tuff interbedded in the upper Cerro Puntudo Formation confirmed a mid-Triassic age (Anisian), allowing a new chronocorrelation along the Cuyo basin.

\section{Materials and methods}

About $4.5 \mathrm{~km}$ of outcrops were mapped in the Cerro Puntudo area (Fig. 2). Two sections were described at 1:1000 and key intervals were evaluated in detail at 1:50. The siliciclastic facies were named following Miall (1977) considering particle size and sedimentary structure, petrography classification of Pettijohn (1975) was used. The carbonate facies of Cerro Puntudo area represent a particular group of terrestrial carbonates with pedogenetic and diagenetic features (Argota et al., 2014; Benavente et al., 2015; Teixeira, 2016); thus Alonso-Zarza and Wright (2009) approach has been used. Microbial carbonates are also a common lithofacies and are classified following Riding (2000). For paleogeography, paleo-slope and streams reconstruction, all significant sediment structures were measured in order to provide a representative vector of paleocurrent direction (Potter and Pettijohn, 1977). The mean vector $(\mathrm{Vm})$ was plotted in rose plots (Allmendinger et al., 2012; Cardozo and Allmendinger, 2013) plus standard deviation $(\sigma)$, consistency factor ( $\mathrm{Fc}$ ) and number of measures (n) (Potter and Pettijohn, 1977). For measurements in conglomerates, "n" represents imbricated clast within a station considering a pool of representative imbricated clasts within a bed.

Additionally, provenance analysis allowed us to interpret source-tosink routes and sediment input. The method of detrital modes of sandstones was adopted following Gazzi (1966) and Dickinson (1970), by counting 300 grains in each thin section. The particles were classified as quartz $(\mathrm{Q})$, including monocrystalline quartz $(\mathrm{Qm})$, polycrystalline 


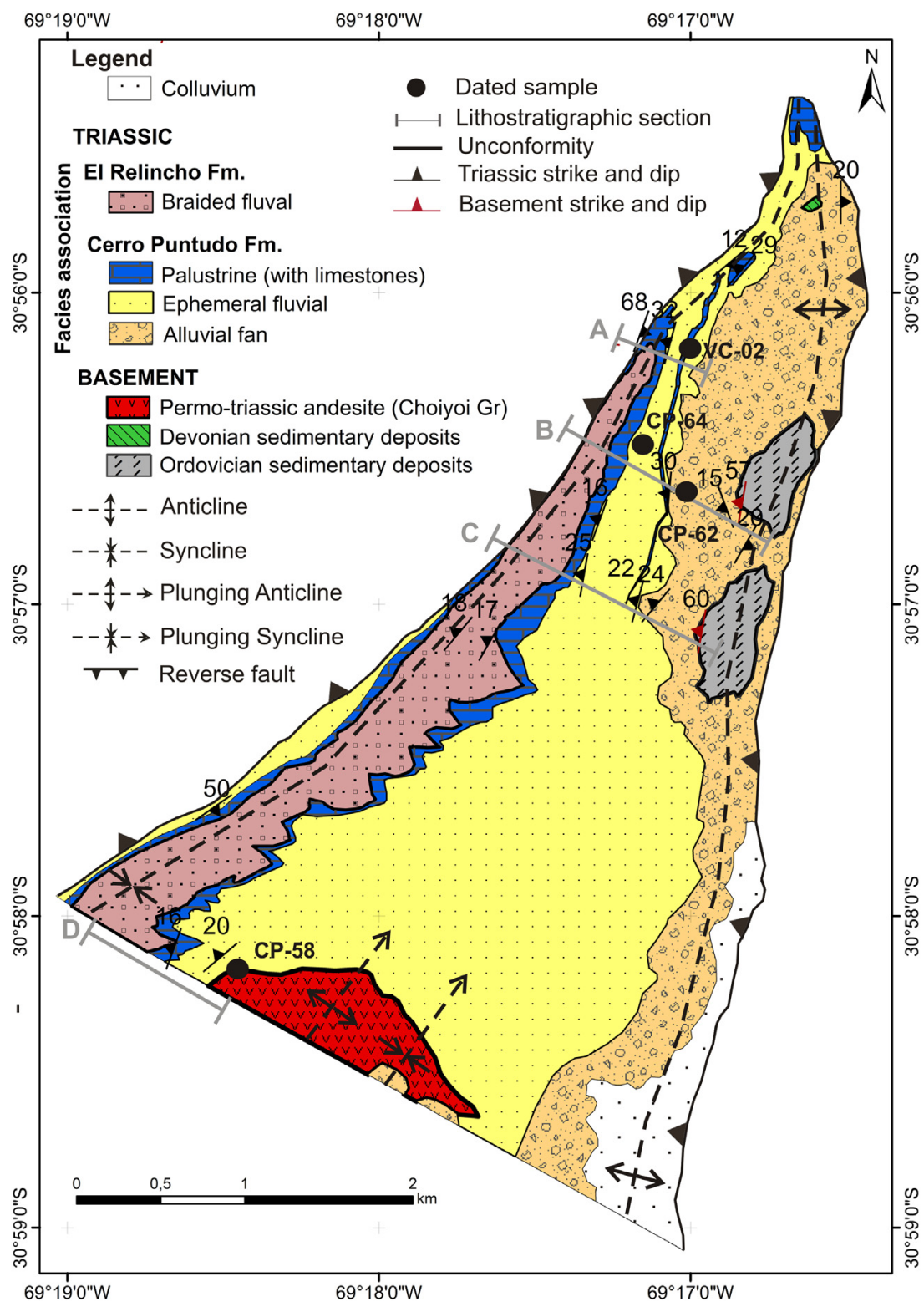

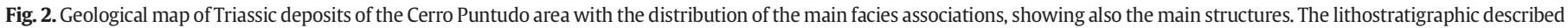
sections are indicated by A, B, C and D; the four dated samples are pointed out as CP-58, CP-62, CP-64 and VC-02.

quartz (Qp); feldspar (F), including plagioclase (P), K-feldspar (K); and lithic fragments (L) of three types: volcanic (Lv), sedimentary (Ls) and metamorphic (Lm). In ternary plots, total lithic (Lt) corresponds to the sum of lithic and polycrystalline quartz. The thin sections were stained with sodium cobaltinitrite to allow the distinction of K-feldspar from plagioclase. However, when the polysynthetic twinning of plagioclase was not evident, the majority of feldspars were classified as indistinct due to the pervasive diagenetic replacing of minerals, such as albite, calcite and clay minerals. In order to solve any doubt related to mineral identification, the thin sections were first analyzed by Scanning Electron Microscopy (SEM)/Energy-Dispersive Spectrometer (EDS). The preparation routine of the samples included polishing, cleaning and carbon metallization before analysis in a JEOL JSM 6010LA with a Silicon-drift EDS operating $40 \mathrm{~s}$ for each detection. Conglomerates were also considered in provenance analysis, but instead of a modal composition, clast frequency counting was applied during field work (Dickinson, 2008). All pebbles, cobbles and boulders were counted and classified in $1 \mathrm{~m}^{2}$ of vertical section, which approximates 100 clasts.

Samples for geochronology were collected in the main tuff layers in the Cerro Puntudo section, which occur only in the Cerro Puntudo formation (Figs. 3, 4). Besides, one andesite sample of the volcanic basement, outcropping to the south and underlying the Triassic stratigraphy, was dated to obtain a minimum age for the Triassic sedimentation. U-Pb ages were obtained by laser ablation multi-collector inductively coupled plasma mass spectrometry (LA-MC-ICP-MS) analyses of zircon grains in the Laboratory for Geochronology of the University of Brasília following methods outlined in Bühn et al. (2009). Samples were loaded into a New Wave UP213 Nd:YAG laser $(\lambda=213 \mathrm{~nm})$, linked to a Thermo Finnigan Neptune Multi-collector ICPMS. Laser induced fractionation of the ${ }^{206} \mathrm{~Pb} /{ }^{238} \mathrm{U}$ ratio was corrected using the linear regression method (Kosler et al., 2002). Masses 204, 206 and 207 were measured with ion counters, and ${ }^{238} \mathrm{U}$ was analyzed on a Faraday cup. For data evaluation, only coherent intervals of signal response were considered. Plotting of U-Pb data was performed using ISOPLOT v.3 (Ludwig, 2003) and errors for isotopic ratios are presented at the $2 \sigma$ level. Because of the statistical treatment applied in calculating Concordia Ages, those are more precise than any individual $\mathrm{U}-\mathrm{Pb}$ or $\mathrm{Pb}-\mathrm{Pb}$ ages (Ludwig, 2003) and, in the present study, always correspond to less than the $2 \%$ accuracy obtained from the intercalibration of the standards. Consequently, the Isoplot calculated errors were modified in order to incorporate this uncertainty 


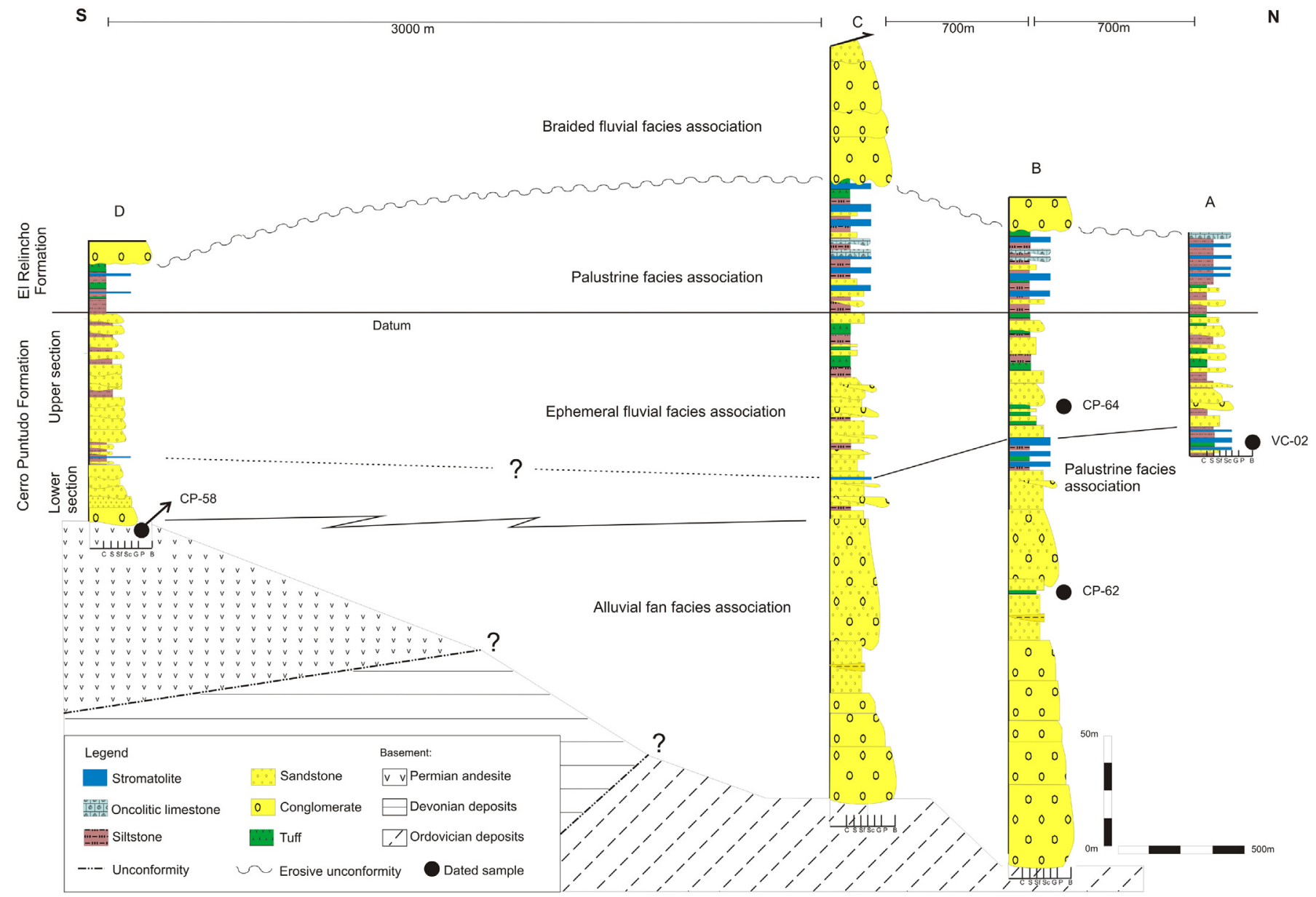

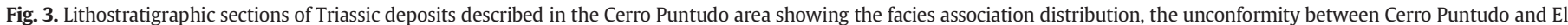
Relincho Formations and the onlap of earlier Triassic deposits over the basement to the south.

level and, hence, represent a more realistic age in terms of the analytical limitations of the method.

\section{Results and interpretations}

\subsection{Geochronology}

Sample CP-58 is a porphyritic andesite with aphanitic matrix and preserved flow texture from the Choiyoi Group basement (Figs. 2-4). The best estimation for the igneous crystallization of this rock is a Concordia age of $256.8 \pm 3.5 \mathrm{Ma}$ (Permian/Lopingian) (Fig. 5A). There is also an older zircon population which yielded the Concordia age of $273.4 \pm 1.8 \mathrm{Ma}$ (Permian/Upper Cisuralian). Both ages are consistent with others ages available for Choiyoi magmatism (Mpodozis and Kay, 1992).

Sample CP-64 is a white tuff with shards, vitroclasts and cemented amygdales, collected in a $1 \mathrm{~m}$ thick layer at the base of the ephemeral fluvial facies association (upper section of the Cerro Puntudo Formation) (Figs. 2-4). The best crystallization age estimation for this rock is a Concordia age of $249.8 \pm 2.5 \mathrm{Ma}$ (Fig. 5B) indicating Lower Triassic. This age is consistent with other ages available in this depocenter. There is also an older inherited zircon population, which yielded the Concordia age of $276 \pm 3.2 \mathrm{Ma}$ (Permian/Upper Cisuralian), equivalent, within error, to the oldest age of CP-58 volcanic basement. Additionally, a few older zircon grains suggest even older inheritance of Proterozoic age.

Sample VC-02 is a cemented tuff with a laminated granular vitric texture collected in a $10 \mathrm{~cm}$ thick layer at the base of the palustrine facies association (upper section of the Cerro Puntudo Formation) (Figs. 2-4). This sample displays a complex age pattern with a large proportion of inherited zircon grains derived from Paleozoic, Proterozoic and even Archean sources. The estimated age for this rock is represented by the weighted mean ${ }^{206} \mathrm{~Pb} /{ }^{238} \mathrm{U}$ age of the youngest grains $254.9 \pm 3.4 \mathrm{Ma}$ (Permian/Lopingian), a probably inherited age.

Sample CP-62 is a reworked silty tuff with green phyllosilicate/clay minerals located in a $60 \mathrm{~cm}$ thick layer toward the top of the alluvial fan association (Figs. 2-4). This tuff bed is the most basal tuff of the Cerro Puntudo section (lower section of the Cerro Puntudo Formation). This sample shows a large proportion of inherited grains, which combined with some degree of lead loss, results in a complex age pattern. Therefore, a reliable age estimation is not possible.

The topmost and thickest tuff layer $(2 \mathrm{~m})$ of the Cerro Puntudo section underlies the erosional unconformity, within the upper palustrine facies association at the top of the Cerro Puntudo Formation. This tuff was previously dated through U-Pb SHRIMP method by Mancuso et al. (2010) and yielded a $243 \pm 1.8 \mathrm{Ma}$ (Middle Triassic) age.

\subsection{Accommodation changes}

Based on the unit thicknesses, stacking patterns and the age constraints described previously, we can interpret accommodation changes over time. This has become a fundamental concept in modern stratigraphic studies and particularly critical for rift settings. Accommodation has been defined as: "the space made available for potential sediment accumulation” (Jervey, 1988). Later work (Muto and Steelb, 2000) has 


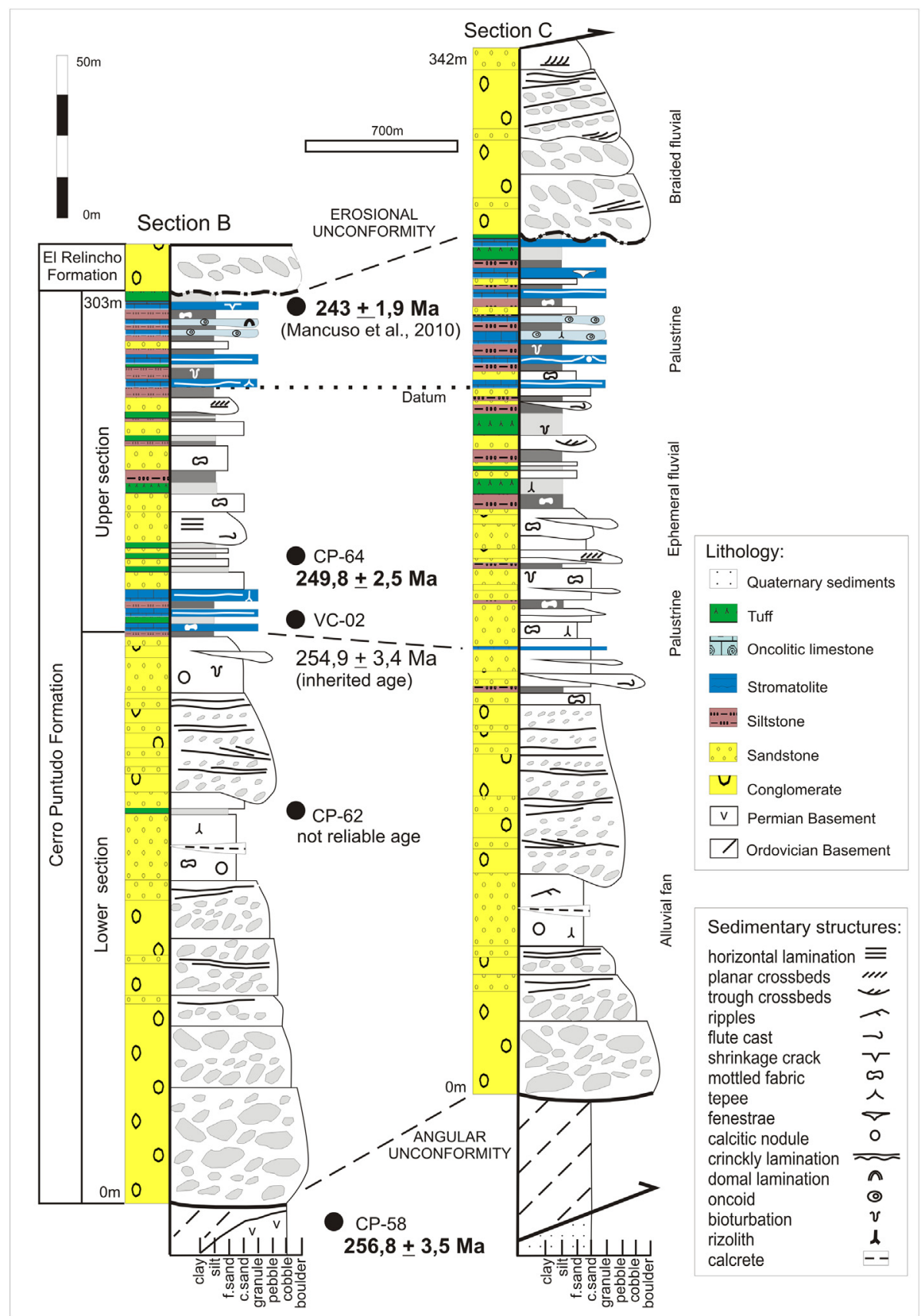

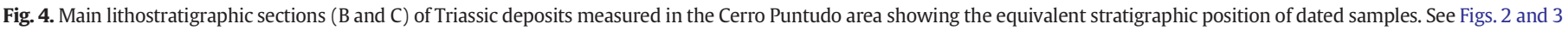
for samples' exact location.

proposed that available space can only be interpreted when appropriate thickness can be measured at a specified site and time in order to infer and discuss high- versus low-accommodation settings (Allen and Fielding, 2007; Ambrosetti et al., 2017). Our age constraints enable us to interpret sedimentation rates for the lower conglomeratic section higher than $25.1 \mathrm{~m} / \mathrm{Ma}$, since the basal age is from the basement, and approximately $20.3 \mathrm{~m} / \mathrm{Ma}$ for the upper half of the Cerro Puntudo Formation. The accommodation change observed within the Cerro Puntudo Formation indicates decreasing available space, which is consistent with the fining upward trend of the unit (Fig. 4). Within a rift setting, these changes point to a transition from an active tectonic accommodation, with higher sedimentary rate, into a more tranquil stage, with a lower deposition rate.

Unfortunately, no constraint can be made on accommodation for the upper El Relincho Formation, since we have no data on thickness and age brackets for the topmost unit. However, stacking pattern analysis allows us to conclude that accommodation accelerates at the base and slowly decelerates toward the top, which is consistent with facies development.

\subsection{Facies and environments}

Within the Cerro Puntudo section, four facies associations could be defined (Fig. 4). Their characteristics are summarized in Tables 1 and 2, in Fig. 6 and more details are described in Teixeira (2016). The lower pinkish section of the Cerro Puntudo Formation is composed of coarse conglomerates of alluvial fan facies association, while the upper reddish section includes finer grained conglomerates, sandstones and shales of ephemeral fluvial facies association, which alternate with two gray sections related to limestones beds of palustrine facies 

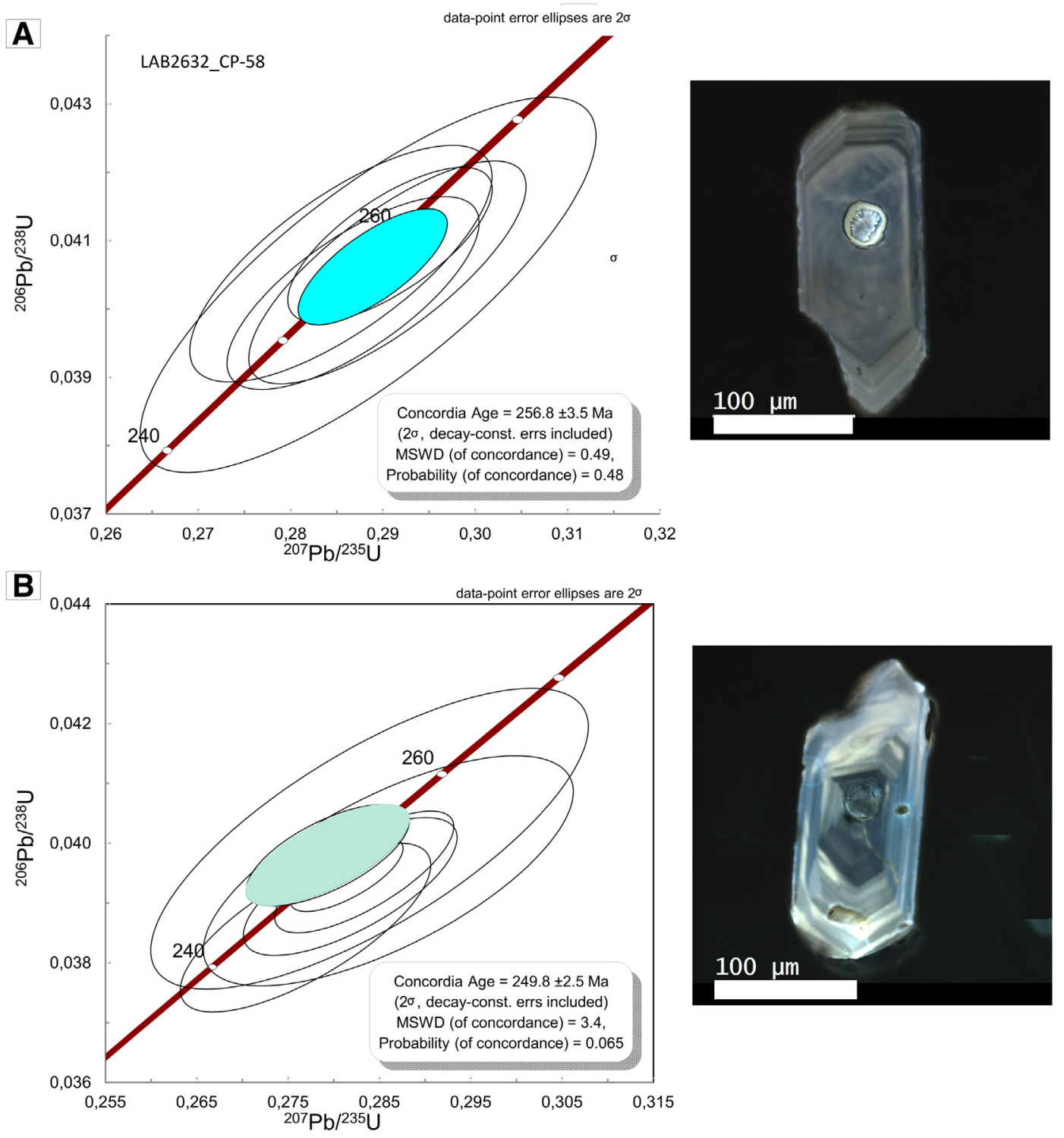

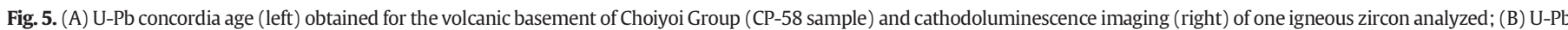
concordia age (left) obtained for a tuff of the upper section of the Cerro Puntudo Formation (CP-64 sample) and cathodoluminescence imaging (right) of one igneous zircon analyzed.

association. The green section of El Relincho formation is composed of coarse conglomerates of braided fluvial facies association.

\subsubsection{Alluvial fan facies association}

The alluvial fan facies association is represented by crudely layered massive boulder-rich orthoconglomerates. Individual beds reach 2-3 m thickness and show amalgamated and irregular contacts with frequent protruding outsized boulders (Figs. 6, 7A). This association is typically composed of disorganized breccias and conglomerates mostly in the range of boulders (of up to $0.9 \mathrm{~m}$ ) to cobble size. A few lenticular layers with imbricated clasts only occur locally. In addition to poorly sorted boulders, cobbles and pebbles there is also an immature sandy matrix. The conglomerates are compositionally homogeneous and dominated by acidic volcanogenic components. Toward the top of this section, the conglomerates gradually show better layering and turn into finergrained massive cobble to pebble-rich orthoconglomerates, with a sandy matrix. Planar crossbedding coarse sandstones with wedge shape and erosive truncations also occur interbedded with imbricated pebble-rich orthoconglomerates.

The poor stratification, bad sorting and scarcity of internal organization point to a predominance of debris-flow deposits and low-transport efficiency processes for the alluvial fan facies association. Outsized boulders and bed thickness indicate matrix strength and high competence of individual flows. These depositional features are more likely related to proximal fan deposits in high-slope gradient, relatively close to marginal faults. Episodic stream-flow deposits and surface reworking are indicated by lenticular geometry, better sorted pebbly beds with imbricated grouped clasts and sandstone wedges with sharp erosive boundaries (e.g., Nemec and Steel, 1984). The better organization and thinning upward layering suggest progressive enlargement of drainage area, lower depositional slopes and more unconfined fluxes.

\subsubsection{Braided fluvial facies association}

The braided fluvial facies association is mainly composed of stratified cobble-rich orthoconglomerate lithofacies. The conglomerates are usually well sorted and polymictic in composition. Discoid to equantshaped well-rounded cobbles, pebbles and boulders are immersed in a greenish sandy matrix with relatively good textural maturity and nonoxidized minerals. Conglomerates include varied volcanic (acid and mafic extremes), and abundant sedimentary and low-grade metamorphic rocks. Crude horizontal stratification in orthoconglomerates ( $\mathrm{m}$ scale bedding) and development of crossbedded sandstone wedges 
Table 1

Summary of main siliciclastic facies.

\begin{tabular}{|c|c|c|c|c|c|}
\hline Facies & Geometry/thickness & Sedimentary structure & Granulometry & Description & Interpretation process \\
\hline Matrix-supported breccia & Tabular/dm & Massive & Pebble & Mud matrix & Cohesive debris flow \\
\hline $\begin{array}{l}\text { Massive boulder-rich } \\
\text { orthoconglomerate }\end{array}$ & Tabular/2-3 m & Massive to crudely layered & Boulder, cobble, pebble & $\begin{array}{l}\text { With outsized boulders, } \\
\text { localized imbricated clasts }\end{array}$ & $\begin{array}{l}\text { Non-cohesive debris flow } \\
\text { with localized stream flow }\end{array}$ \\
\hline $\begin{array}{l}\text { Massive pebble-rich } \\
\text { orthoconglomerate }\end{array}$ & Tabular/m/dm & Massive & Pebble, cobble & Sand matrix & Non-cohesive debris flow \\
\hline $\begin{array}{r}\text { Stratified cobble-rich } \\
\text { orthoconglomerate }\end{array}$ & Lens/2-3 m & $\begin{array}{l}\text { Horizontal and large } \\
\text { low-angle crossbedding }\end{array}$ & Cobble \pm boulder/pebble & $\begin{array}{l}\text { With imbricated clasts and } \\
\text { sandy matrix }\end{array}$ & $\begin{array}{l}\text { Traction in turbulent } \\
\text { stream-flow current }\end{array}$ \\
\hline $\begin{array}{l}\text { Imbricated pebble-rich } \\
\text { orthoconglomerate }\end{array}$ & Lens $/ 30-60 \mathrm{~cm}$ & $\begin{array}{l}\text { horizontal stratification, } \\
\text { Imbricated clasts }\end{array}$ & Pebble & With normal grading & Traction in turbulent flux \\
\hline $\begin{array}{l}\text { Normally graded fine-grained } \\
\text { conglomerate }\end{array}$ & Lens $/ 30 \mathrm{~cm}-1,5 \mathrm{~m}$ & Normal grading & Pebble/cobble & $\begin{array}{l}\text { Rich-sand orthoconglomerate } \\
\text { poorly sorted }\end{array}$ & Deposition by turbulent flux \\
\hline Planar crossbedding sandstone & Wedges $/ 20-40 \mathrm{~cm}$ & Low angle planar crossbeds & Medium to coarse & $\begin{array}{l}\text { With pebbles in the base and } \\
\text { erosive truncations }\end{array}$ & $\begin{array}{l}\text { Traction in lower flow regime } \\
\text { (dunes 2D) }\end{array}$ \\
\hline $\begin{array}{l}\text { Horizontally laminated } \\
\text { sandstone }\end{array}$ & Lens $/ 30 \mathrm{~cm}-1,5 \mathrm{~m}$ & $\begin{array}{l}\text { Horizontal lamination, } \\
\text { massive }\end{array}$ & Coarse to fine & $\begin{array}{l}\text { With pebble lags, flute casts, } \\
\text { parting lineation, locally mottled }\end{array}$ & Traction in upper flow regime \\
\hline $\begin{array}{l}\text { Through crossbedding } \\
\text { sandstone }\end{array}$ & $\begin{array}{l}\text { Tabular or } \\
\text { wedges } / 10-80 \mathrm{~cm}\end{array}$ & Trough crossbeds & Fine to medium & With erosive truncations & $\begin{array}{l}\text { Traction in lower flow regime } \\
\text { (dunes 3D) }\end{array}$ \\
\hline Climbing ripple sandstone & Sheets, lens/10-20 cm & Climbing ripples & Fine & $\begin{array}{l}\text { With erosive bottoms, calcitic } \\
\text { nodules and bioturbation }\end{array}$ & $\begin{array}{l}\text { Suspension in lower flow } \\
\text { regime }\end{array}$ \\
\hline Laminated fine-grained mud & Tabular/10 cm-2 m & $\begin{array}{l}\text { Lamination, mottled, } \\
\text { bioturbation }\end{array}$ & Silt/mud & $\begin{array}{l}\text { Heterolithic lamination of } \\
\text { silt/mud, calcitic nodules, } \\
\text { mud cracks }\end{array}$ & $\begin{array}{l}\text { Decantation, eodiagenesis } \\
\text { and pedogenesis }\end{array}$ \\
\hline Massive fine-grained mud & Tabular/10-50 cm & Mottled, bioturbation & Silt/mud & Calcitic nodules & $\begin{array}{l}\text { Decantation eodiagenesis } \\
\text { and pedogenesis }\end{array}$ \\
\hline Bioturbated tuffs & Tabular/10 cm-2 m & $\begin{array}{l}\text { Massive, normal grading, } \\
\text { bioturbation }\end{array}$ & Silt to sand & $\begin{array}{l}\text { Volcaniclastic (glass and } \\
\text { shards) mottled }\end{array}$ & Ash-fall deposits \\
\hline Laminar calcretes & Nível tabular/5-10 cm & Rhizoliths & Silt to sand & $\begin{array}{l}\text { Micritic irregular } \\
\text { carbonate-rich layers }\end{array}$ & $\begin{array}{l}\text { Calcretization pedogenic } \\
\text { processes }\end{array}$ \\
\hline
\end{tabular}

highlight good internal organization with lenses of imbricated clasts and grouped boulders (Figs. 6, 7C). Internal bounding surfaces contain common cut and fill structures and normal gradation. Planar and trough crossbedding sandstones are more frequent toward the top. These facies are medium to coarse-grained well-sorted sandstones. They usually show internal low-angle surfaces and truncations by intervening $\mathrm{dm}$ thick layers of medium to coarse-grained imbricated pebble-rich orthoconglomerates. Within this association, meter-scale cycles with sharp irregular to undulate bases and normal gradation are frequent.

The stratified cobble-rich and sandy orthoconglomerates are interpreted as longitudinal bars (Miall, 1996) formed by turbulent stream-flow currents within channel braided belts. The planar and trough crossbedding sandstones are interpreted as sandy bedforms (2D and 3D dunes) deposited by traction adjacent to the conglomerate bars during low-stage flows. Individual cycles may be fluctuations between high and low discharge gravel-rich braided streams. Horizontal and large-scale crossbedding is compatible with developing bars, whereas low-angle erosional surfaces seem to be reactivation surfaces. Crude bedding and relatively good internal organization are features characterizing stream-flow dominated alluvial fans (or distributive braided systems) with available water sources all year long. This explains the profusion of crossbedding and the well-rounding of individual pebbles-boulders within this clast-supported conglomerates.
Lenticular bedding characterizes frequent channel switching and the intervening sandstones and lag conglomerates indicate fluctuating flow regimes. The textural patterns and diversity of tractive structures within this facies together with the sandy matrix of the conglomerates indicate more humid conditions for this facies association. Especially the green color of the sandy matrix reveals that associated iron minerals were not fully oxidized. This is in contrast with the conglomerates at the base of the Cerro Puntudo Formation.

\subsubsection{Ephemeral fluvial facies association}

The ephemeral fluvial facies association is characterized by fining upward thin bedded cycles $(\sim 0.5-1.5 \mathrm{~m})$ composed of horizontally laminated sandstones encased within laminated fine-grained mud (Figs. 6, 7B). In addition, the ephemeral fluvial association shows a wide spectrum of lithofacies: thin lenticular beds of normally graded fine-grained conglomerates, fine-grained thin-bedded tabular climbing ripples sandstones, bioturbated tuffs and laminar calcretes.

Horizontally laminated sandstone is the recurrent lithofacies within this association. Beds are lenticular with erosive concave base and planar top, $0.3-1.5 \mathrm{~m}$ thick and 3-15 m long. These sandstones are submature, medium to coarse-grained, with iron oxides represented by red film coatings around individual grains. This facies shows a variety of primary sedimentary structures, such as flute casts, horizontal

Table 2

Summary of the carbonate facies (palustrine limestones).

\begin{tabular}{|c|c|c|c|c|c|}
\hline $\begin{array}{l}\text { Carbonate } \\
\text { facies }\end{array}$ & Grain size/thickness & Sedimentary Structure & Description & Micro-biota & Interpretation process \\
\hline Stromatolite & Tabular/dcm to $\mathrm{m}$ & $\begin{array}{l}\text { Rhizolith, tepee, shrinkage } \\
\text { crack, breccia (paleosoil), } \\
\text { enterolithic layers }\end{array}$ & $\begin{array}{l}\text { Micritic crenulated lamination } \\
\text { (locally domic) with fenestral and } \\
\text { calcitic (rare barite) nodules; } \\
\text { recurrent siliciclastic silt intercalation }\end{array}$ & Some ostracods & $\begin{array}{l}\text { Microbial carbonate precipitation in } \\
\text { ponds under more evaporative } \\
\text { conditions; pedogenesis and vadose } \\
\text { eodiagenesis }\end{array}$ \\
\hline $\begin{array}{l}\text { Oncolitic } \\
\text { limestone }\end{array}$ & Tabular or lens/dcm & $\begin{array}{l}\text { Disrupted/broken oncoids, } \\
\text { rhizolith, inverse grading, } \\
\text { cemented fissures }\end{array}$ & $\begin{array}{l}\text { Micrite/peloidal matrix with siliciclastic } \\
\text { silt and heterogeneous oncoids }\end{array}$ & Ostracods, charophytes & $\begin{array}{l}\text { Microbial carbonate precipitation } \\
\text { in ponds; pedogenesis and vadose } \\
\text { eodiagenesis }\end{array}$ \\
\hline Mudstone & Tabular (?)/cm & Massive, contraction crack & Massive homogeneous mudstone & Ostracods, rare charophytes & $\begin{array}{l}\text { Carbonate precipitation under less } \\
\text { evaporative conditions; vadose } \\
\text { eodiagenesis }\end{array}$ \\
\hline
\end{tabular}




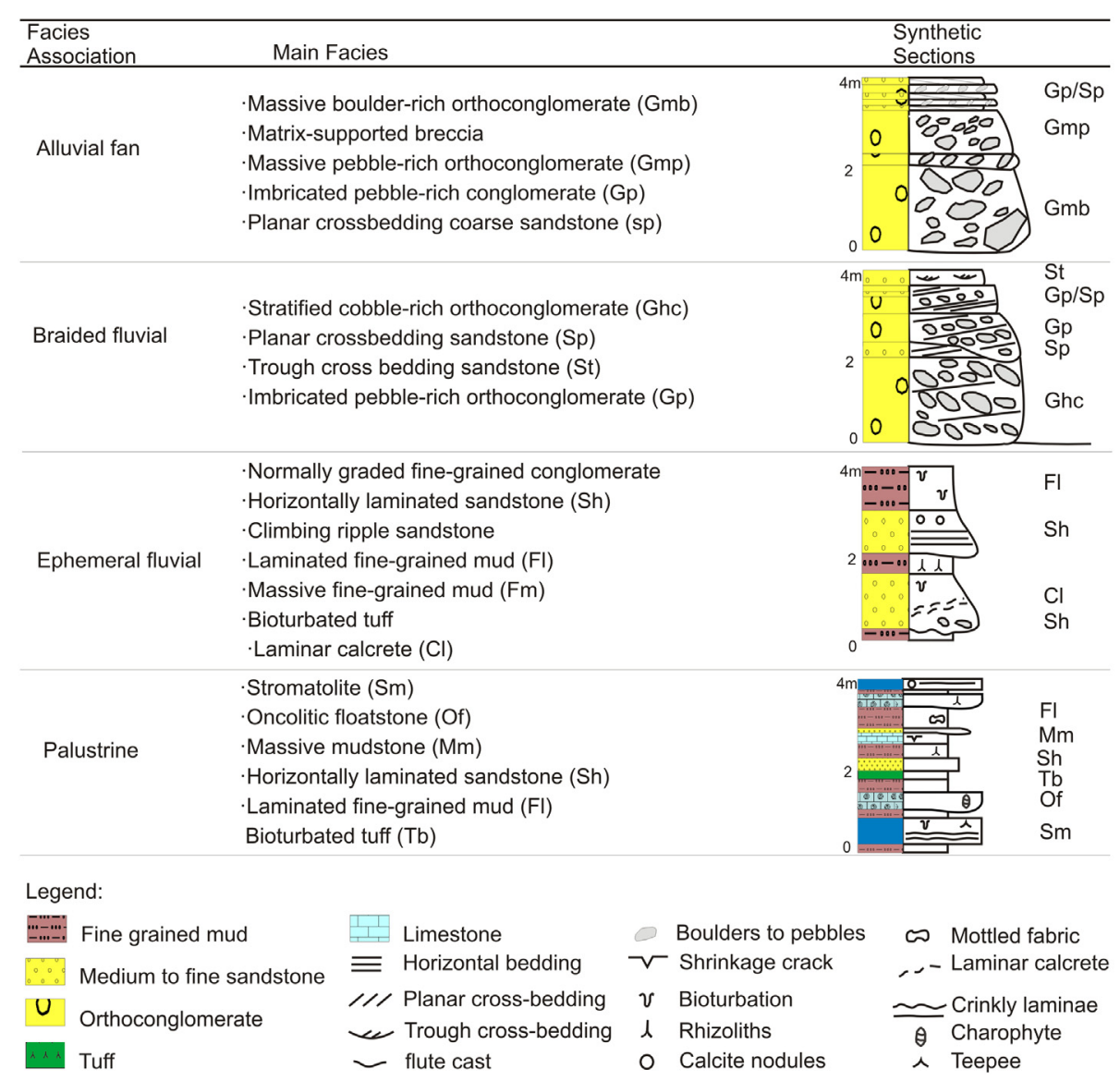

Fig. 6. Summary of the main facies and facies associations in the Cerro Puntudo area.

lamination and parting lineation. Besides, there are secondary sedimentary structures, like mottled textures, carbonate nodules and bioturbation.

Laminar calcretes are characterized by irregular carbonate-rich layers, slightly discordant with the bedding, and with vertical tubular structures, typically bifurcated at the base. Under the microscope, they show micrite-rich peloidal-clotted textures with fenestral and alveolar growth, circumgranular shrinkage cracks and carbonate crusts around the oval tubes. This facies occurs laterally associated to horizontally laminated sandstones.

Laminated and massive fine-grained mud lithofacies are represented by tabular beds, $0.1-0.5 \mathrm{~m}$ thick, overlying the horizontally laminated sandstones. They consist of red to purple heterolithic alternation of silt and mud with some sand grains and shards/vitroclasts. This facies has mottled texture, carbonate nodules and superposed cylindrical to oval tubes with various diameters and positions. Minor greenish to whitish pervasively bioturbated tuffs $(<0.1 \mathrm{~m})$ with abundant finegrained glass shards also occur.

This facies association largely reflects an environment with little slopes dominated by deposition of fine-grained rocks punctuated by normally graded and channelized laminated sandstones. Lenticular horizontally laminated sandstones are compatible with relatively shallow channels. Their erosive bases with flute casts and parting lineation indicate flash-flood deposits. Few isolated and more incisive channels with conglomerate lags may represent wadis-type events or shallow distributaries within ephemeral fluvial distributary systems and terminal fans (Nichols and Fisher, 2007). The finer-grained caps with lenticular to wavy bedding (climbing ripple sandstone) and mudcracks indicate a final stage of deposition in shallow water ponds or largely unconfined mudflats. Massive fine-grained muds represent deposits formed by settling of fines in remnant channel or inter-channel areas, related to the waning stages of the flash floods. Subtle to pervasive mottling, carbonate nodules and tube-like structures are indicative of eodiagenetic features, probably related to fluctuating water table. The microscopic features within the laminar calcretes record typical pedogenic processes (Esteban and Klappa, 1983) together with development of vertical tubular structures interpreted as rhizoliths and already mentioned by Mancuso (2009). Bioturbated tuffs represent ash-fall deposits within this ephemeral fluvial system and into shallow ponds. This facies yields little preservation potential and was largely transformed into some kind of incipient paleosoil (Platt and Wright, 1992). These characteristics are common in ephemeral fluvial systems, where fluvial sediments are laid down under more humid environmental conditions (flooding) and pedogenesis, eodiagenesis and bioturbation occur during later drier stages with a fluctuating water table. Similar conclusions were inferred from trace fossil assemblages (Krapovickas et al., 2008).

\subsubsection{Palustrine facies association}

The palustrine facies association is separated from the ephemeral fluvial association by the presence of thin carbonate units that occur interbedded (at a dm to $\mathrm{m}$ scale) within the brown to red fine-grained muds and the greenish to whitish bioturbated tuffs. A main characteristic throughout this carbonate-rich facies association is the pervasive pedogenetic/eodiagenetic overprint affecting the different primary features (Fig. 7D)

Carbonate thickness within this facies association never exceeds $1 \mathrm{~m}$ and lithotypes usually contain a low-percentage of siliciclastics or glass shards dispersed in the matrix. The remaining lithofacies, mostly the siliciclastic fine-grained fines and tuffs (Fig. 7E), are usually affected by strong bioturbation and show a diversity of tubes (rhizoliths) of various diameters. Minor channels with coarser-grained siliciclastics may suddenly interrupt or truncate carbonates, but usually intergrade 

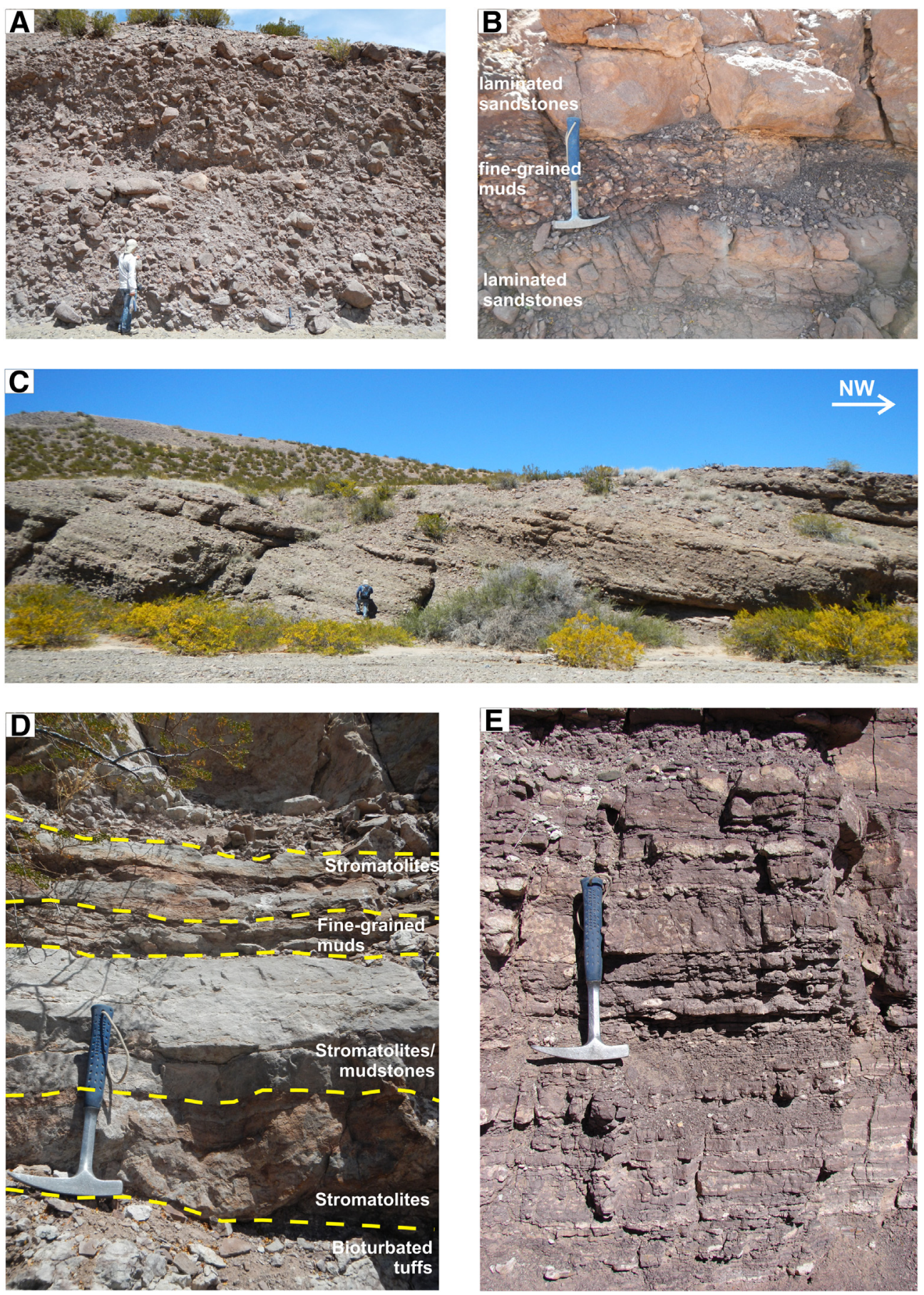

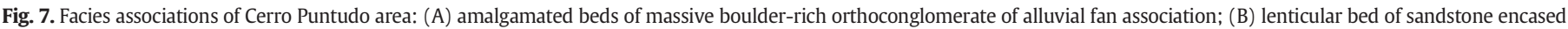

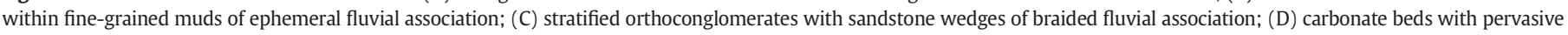
pedogenetic/eodiagenetic features of palustrine association; (E) siliciclastic fine-grained muds and tuffs with pedogenetic features of palustrine association.

generating transitions from silty-sandy carbonates to arenaceous and silty mudstones.

Carbonate rocks are massive mudstones, stromatolites (very finely laminated mudstones) and oncolitic floatstones. Massive mudstones show few isolated ostracods and pervasive cracking throughout the beds (Fig. 8A). Stromatolites are usually planar to crinkly laminated. In addition, teepee-like features (Fig. 8B), irregularly folded layers and nodular patterns are present. Some domal hemispheroidal stromatolites occur associated with oncoids (Fig. 8C). Oncolitic floatstones are composed of poorly-sorted oncoids ranging in size from $\mathrm{mm}$ to over a $\mathrm{cm}$ (Fig. 8D), including beds with internal grading. Oncoids are usually nucleated and asymmetric to eccentric (Fig. 8E) and internally show various stages of growth and erosion-truncation. Directional growth seems common and usually is characterized by asymmetric shapes (Fig. 8F). Preserved filament structures growth of possible microbial origin can be observed under the microscope (Fig. 8G). Nuclei are usually remains of charophyte plants (e.g. broken thalli, gyrogonites), phytoclasts, or intraclasts (Fig. 8F).

All of these carbonate facies show some degree of earlier pervasive admixing (bioturbation), shrinkage cracks and later development of fenestral and microkarstic dissolution cavities. These voids have a variety of superposed cementations, including vadose silts and sparry to radial acicular fan-shaped calcites. Matrix neomorfism and circumgranular 

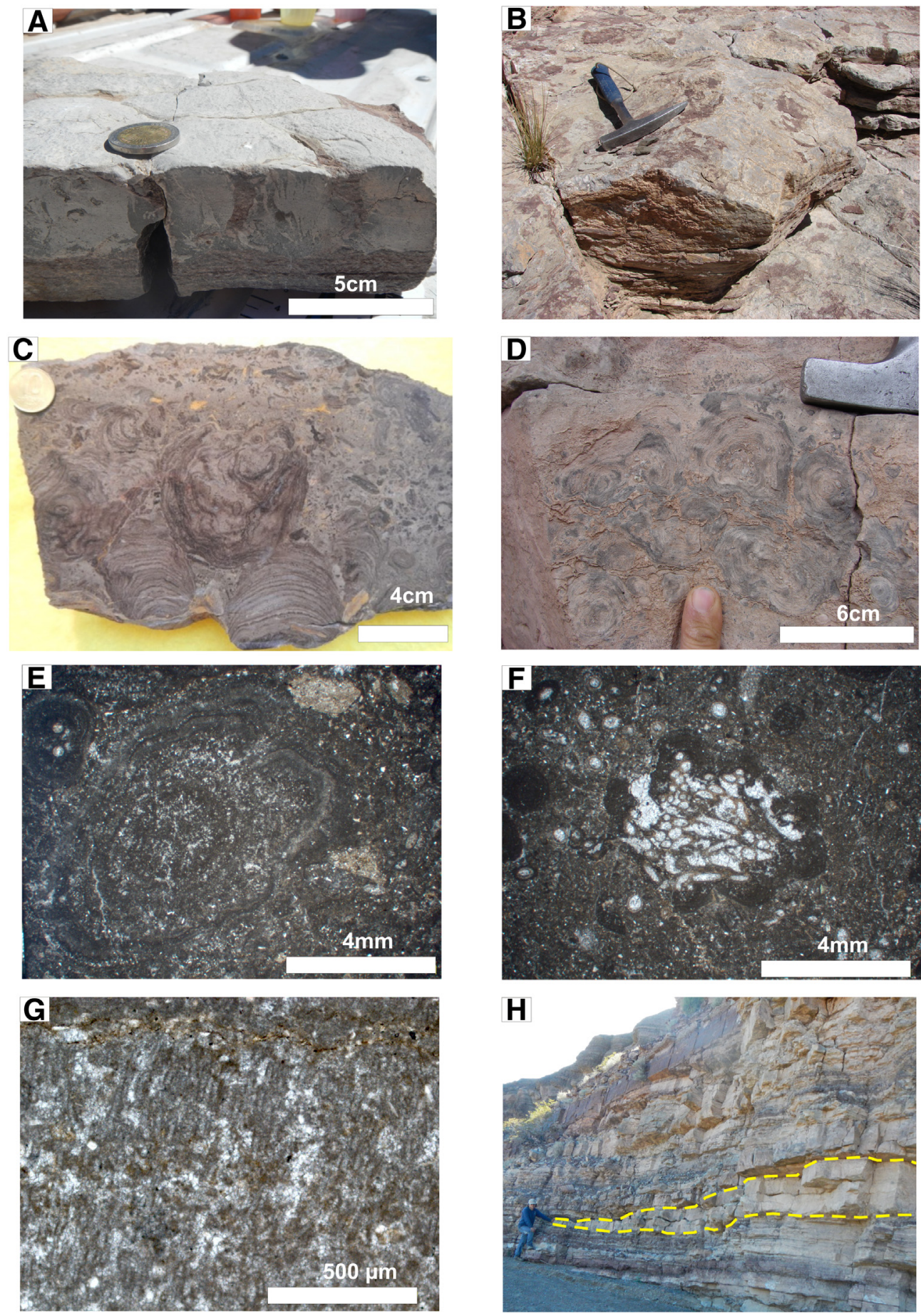

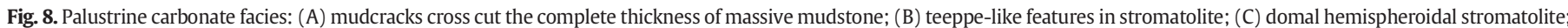

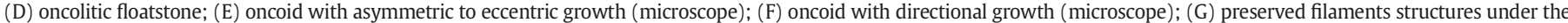
microscope; $(\mathrm{H})$ two distinct bedding styles: horizontal and lenticular (highlighted).

cracking are also pervasive throughout these carbonates. Sometimes bioturbation completely erases the primary characteristics giving a massive appearance to the beds.

Within this association two distinct bedding styles (Fig. $8 \mathrm{H}$ ) are represented by lenticular bedsets with $\sim 20 \mathrm{~m}$ length of individual thin-bedded limestones of the oncolitic type carbonates, and laterally continuous sheet-like bedding style carbonates (beds up to $0.45 \mathrm{~m}$ thick), represented by crinkly to hemispheroid stromatolites at the base and more planar type (carbonate laminites) toward the top or by mudstone layers. Limited lateral extent and thickness of the limestone beds indicate the local nature of the carbonate fabric within this environment. More tabular facies seem to represent mudflats of extremely shallow lakes (Gierlowski-Kordesch, 2010), whereas more lenticular strata may indicate ponded facies within fluvial ephemeral channels (e.g., Arenas et al., 2015).

Stromatolite facies affected by bioturbation and cracking seem marginal to ponded waters and point to frequent subaerial development. Teepee structures, nodular fabrics and enterolithic folding appear to relate to evaporite precipitation under more negative hydrological balance during drier seasons. Ostracod-rich mudstones may record the deeper water environments within this association. However, latestage mudcracks cross cut the complete thickness (Fig. 8A) suggesting 
subsequent subaerial exposure and desiccation. Gradation of oncoid size within individual beds of oncolitic floatstones together with little sorting and mixture with various size broken pieces may indicate some transport and in situ exposure, breakage and reworking of carbonate grains within this extremely shallow water environment and/or fluvial swamps. Fragmented oncoids as well as mixed and mottled matrices may indicate various degrees of soft-sediment bioturbation before the final cementation. Iron-rich crusts and cemented tubes crosscutting beds have been suggested as strong evidence for exposure and late pedogenesis (e.g., Alonso-Zarza and Wright, 2009). Given the fact that all of the carbonate facies, including the oncoid floatstones, show early admixtures and deformation due to soft-sediment bioturbation (soft ground patterns), color changes and superposed contraction features (circumgranular cracks), pore generation and enlargement (microtubes, fenestrae and voids in the matrix) and cementation, we infer protracted exposure, partial desiccation, oxidation and pedogenetic processes. This is common in carbonate-rich marshes affected by water table fluctuations and recurrent vadose diagenetic conditions.

The scarcity of siliciclastic facies reveals a relatively tranquil stage with little external supply and climatic conditions prone to development of carbonate factories. Floodplain depositional environments with ponds and secondary drainages within marshlands may have dominated this association. Ponds may have developed alkaline conditions with saturation of calcium carbonates, while the secondary carbonate features seem a product of seasonal water table fluctuation during drier episodes (e.g., Verrecchia, 2007). These alternating conditions are characteristic of palustrine/wetland systems that are seasonally flooded and seasonally exposed to vadose eodiagenesis and/or pedogenesis substrates (Platt and Wright, 1992; Verrecchia, 2007; Alonso-Zarza and Wright, 2009). This interpretation differs from previous work that suggested lacustrine and shallow lacustrine environments (López-Gamundí and Astini, 2004; Mancuso, 2009; Benavente et al., 2012) for this facies association and agrees with the recent interpretation by Benavente et al. (2015), who characterized palustrine carbonates for this succession.

\subsection{Provenance analysis}

\subsubsection{Conglomerates}

Preliminary clast counting showed a great homogeneity throughout the alluvial fan conglomerates of the Cerro Puntudo Formation. A representative clast counting $20 \mathrm{~m}$ from the base of this section (Fig. 9, label A; Appendix A) shows a largely volcanic population (97\%) composed of andesites, rhyolites and tuffs of dominant pinkish to reddish colors. No compositional differences occur between boulder and pebble sizes, although few purple boulders of volcanic breccias and agglomerates (3\%) were found in the coarser populations.

Compositional difference in these conglomerates occurs only within the lowermost $5 \mathrm{~m}$, immediately overlying the angular unconformity at the base of Cerro Puntudo. As much as 50\% of the boulder-cobble-pebble sizes (Fig. 9) are composed of sandstones and slightly metamorphosed graywackes that clearly come from the underlying Ordovician basement rocks. This clast sedimentary composition rapidly disappears up section.

Two representative clast-count stations within the braided fluvial conglomerates of El Relincho Formation (Fig. 9, labels B and D; Appendix A) show a large compositional variation. There are abundant metamorphic green clasts (19-12\%), besides intermediate to acidic volcanic clasts (81-88\%), which are similar to those of the Cerro Puntudo Formation. The metamorphic fragments are meta-sedimentary (light to olive green) and meta-mafic (dark green) with pervasive foliation, whereas volcanic fragments are andesite, rhyolite and ignimbrite (pink, reddish and purplish color). Close to the base of the El Relincho Formation ( $5 \mathrm{~m}$ from the base), metamorphic fragments are more frequent among the pebble size population (47\% in label C), but also occur as cobbles (19\% in label B, $12 \%$ in label D). Among the cobble-size population, differences within the volcanic clasts are recorded up section: next to the erosional unconformity of El Relincho Formation (label B), andesites and rhyolites are in similar proportions, while toward the top (label D), rhyolite cobbles are twice as abundant as andesites.

Lower and upper conglomerates strongly differ in composition. Whereas the lower Cerro Puntudo Formation contains only volcanic clast populations, the upper El Relincho Formation shows an input of metamorphic components, besides volcanic clasts. This notable polymictic composition suggests a change in provenance. In addition, this compositional change is largely responsible for the sharp color change toward greenish in the El Relincho Formation. This is a great contrast to the red-bedded Cerro Puntudo Formation.

Andesite clasts of the Cerro Puntudo Formation have a remarkable similarity in composition, petrographic textures and colors with the volcanic basement outcropping to the south of the area (Fig. 2) and dated in this work (sample CP-58, Figs. 2, 3 for location). PermoTriassic rhyolites outcrop in separate hills immediately to the west of the study area (Fig. 1), including the top of Cerro Puntudo hill. These volcanic rocks are considered part of the Choiyoi acidic volcanism (Mpodozis and Kay, 1992) widespread across the Frontal Cordillera to the west and also present within the western Precordillera (Jenchen and Rosenfeld, 2002; Ávila et al., 2006; Barredo et al., 2012).

The compositional departure within the basal lowermost $5 \mathrm{~m} \mathrm{sec}-$ tion of the Cerro Puntudo Formation, with abundant sandstone and metagraywacke clasts, seems to be related to the fact that locally the conglomerates onlap onto Ordovician basement rocks (Fig. 3). This is compatible with the angular unconformity mapped at the base of the Cerro Puntudo Formation (Fig. 2) allowing the interpretation of a hanging wall depositional surface. Thus, some rework of the local basement provided the sedimentary and metagraywacke clasts contrary to the rest, which points to a source in the volcanic footwall.

On the other hand, metamorphic and sedimentary clast compositions in the El Relincho Formation are compatible with those in the western Precordillera. Outcrops of low-grade metamorphic rocks, including metagraywackes and mafic units and a variety of sedimentary rocks, occur in the western Precordillera, immediately east and southeast of the study area, and belong to Ordovician, Silurian, Devonian and Carboniferous units (Fig. 1).

\subsubsection{Sandstones}

The modal composition of sandstones was carried out in 10 thin sections, seven in the Cerro Puntudo Formation and three in matrix and sandstone patches within the El Relincho Formation, summarized in Fig. 9 and Appendix B.

Monocrystalline quartz is euhedral, with embayment fractures, typical of a volcanic origin. It occurs in the whole section, but with higher proportions (2-18\%) at the top. This increasing content is consistent with rising felsic volcanic grains (rhyolite) up section. Another type of monocrystalline quartz that is observed is sub-rounded with a previous syntaxial cement, both of which are features generated by reworking of sedimentary rocks. Recycled sedimentary monocrystalline quartz is locally significant (as much as $8 \%$ ) next to the base of the Cerro Puntudo Formation, associated with sandstone boulders reworked from the underlying basement. It increases to $12 \%$ toward the top in El Relincho Formation, associated with metamorphic and lithic sedimentary grains and polycrystalline quartz.

Polycrystalline quartz grains are sub-rounded and composed of anhedral or elongate/stretched internal crystals, with undulose extinction that is a granoblastic texture typical of metamorphic grains. Subrounded polycrystalline quartz as well as monocrystalline quartz grains occur locally at the base of the Cerro Puntudo Formation and more importantly in El Relincho Formation (2-8\%).

Feldspars are significant components in all samples, varying between 17 and 47\%. They are of two types, plagioclases or K-feldspars, but they are usually recrystallized to albite, calcite and muscovite. When distinction between them was not possible due to pervasive diagenesis, grains were classified as indistinct feldspars (Appendix B). 


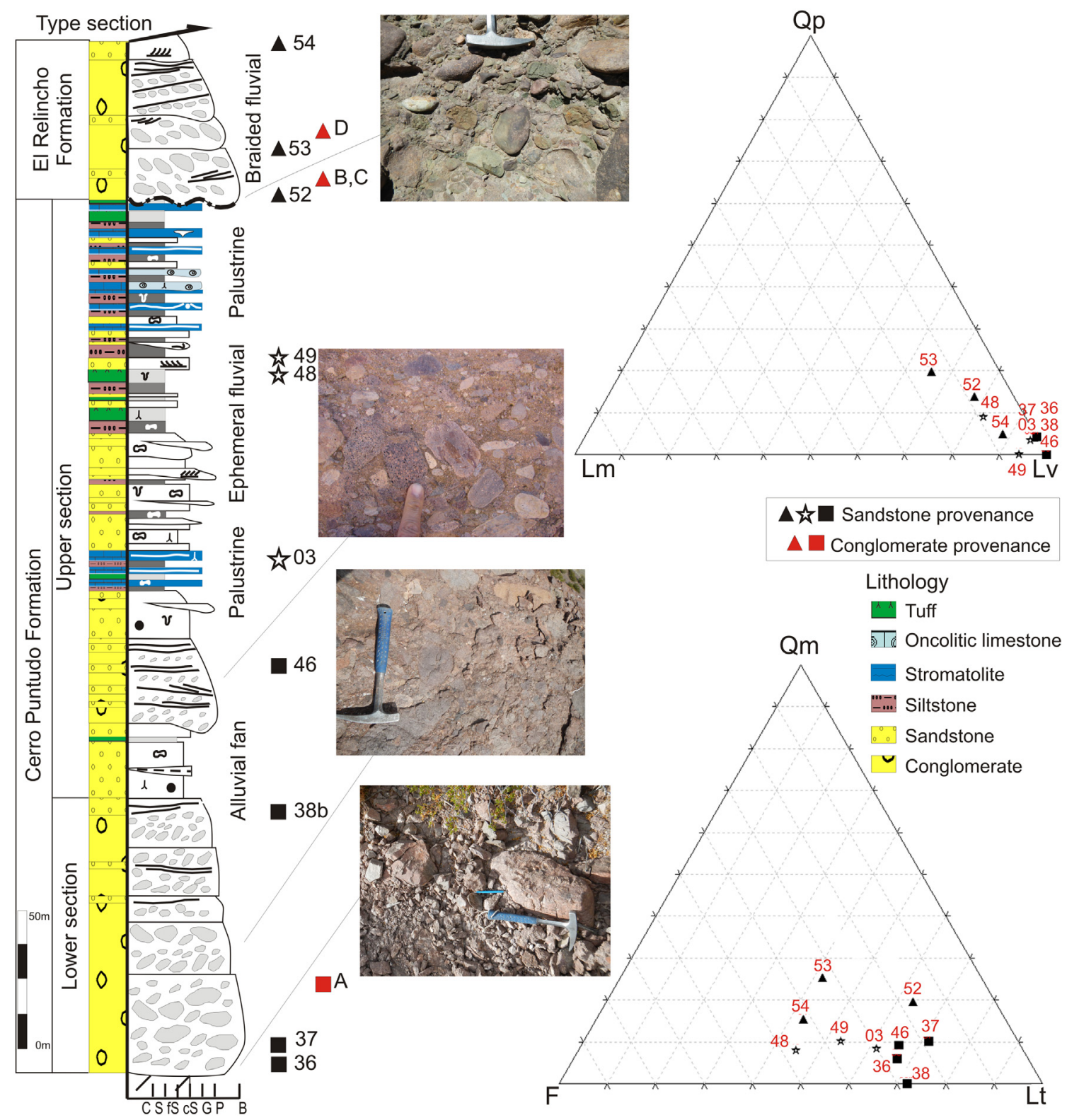

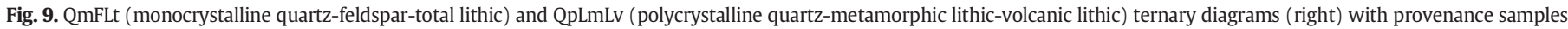

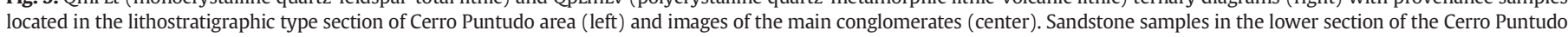

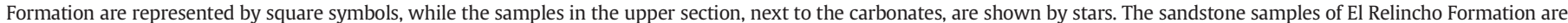
represented by triangles. The conglomerate counting stations are labeled as A, B, C and D in the type section.

The volcanic lithic fragments are substantial components throughout the section with proportion ranging between 27 and $72 \%$. They are the exclusive type of lithic fragments (100\%) within the lower section of the Cerro Puntudo Formation, the majority (90-100\%) within the upper section and still a very important part (77-93\%) in the El Relincho Formation. According to their textures, grains can be classified as porphyritic, felsitic and lathwork. Porphyritic textures are more abundant in Cerro Puntudo lower section; they contain plagioclase, feldspar and subordinate oxidized amphibole and biotite as phenocrysts in a potassium/sodium microcrystalline matrix, which characterizes andesitic compositions. Felsic textures occur in constant proportion in the entire section; they are aphanitic with silicic to potassium/sodium matrix and some quartz and feldspar (chessboardtwinned albite) phenocrysts, and usually derive from rhyolites/ rhyodacites. Some of these grains contain glass and glass shards that characterize pyroclastic deposits (ignimbrites and welded tuffs). Lathwork textures with equigranular euhedral plagioclases of probably andesitic composition occur only locally within the lower section of the Cerro Puntudo Formation.

Metamorphic lithic fragments occur locally within the upper section of the Cerro Puntudo Formation (1-4\%) and more frequently in El Relincho Formation (3-7\%). Two types are recognized: metasedimentary (meta-siltstones and meta-sandstones), that are the most common types, and mafic grains, which seem more important in El Relincho Formation. All these lithic fragments show well developed foliations, and those derived from sedimentary rocks show finegained micas grown oblique to lamination.

Sedimentary lithic fragments are siltstones and fine grainedsandstones that occur only locally at the base of the Cerro Puntudo Formation and between 1 and 5\% in El Relincho Formation. Sandstone fragments are $<1 \%$ since they are usually counted separately as sand grains (Gazzi-Dickinson method).

According to their composition in total quartz-feldspar-lithic fragment (Qt-F-Lt) plots (Pettijohn, 1975) all sandstones are litharenites 
to feldspathic litharenites with little primary matrix and show a variety of cements (primarily calcite, quartz and hematite). Distinct provenance can be interpreted from triangular plots including lithic fragments (volcanic lithic, sedimentary lithic, metamorphic lithic, polycrystalline quartz, total lithic) or minerals (monocrystalline quartz, plagioclase, K-feldspar, feldspar, total quartz) (Dickinson, 1985). Monocrystalline quartz-feldspar-total lithic ( $\mathrm{QmFLt}$ ) and polycrystalline quartzmetamorphic lithic-volcanic lithic (QpLmLv) plots were used for this study (Fig. 9). The ternary diagram shows that samples of Cerro Puntudo lower section (Fig. 9, square labels 36, 37, 38b, 46) are dominated by volcanic lithic fragments, moderate feldspars, and low volcanic quartz. Samples 36 and 37 show recycled monocrystalline quartz from the basement. Samples of Cerro Puntudo upper section (Fig. 9, star labels $03,48,49$ ) are dominated by volcanic lithic fragments, but yield a higher feldspar content and some volcanic quartz. Samples of El Relincho Formation (Fig. 9, triangle labels 52, 53, 54) show a higher proportion of more mature monocrystalline quartz, besides polycrystalline quartz, metamorphic, sedimentary and volcanic lithic grains, as evidenced by the polycrystalline quartz-metamorphic lithic-volcanic lithic diagram (Fig. 9).

The modal composition of sandstones and ternary plots show that samples from the Cerro Puntudo Formation have a volcanic source. The same conclusion was drawn independently from the composition analysis in the alluvial fan conglomerates. According to the prevailing volcanic compositions we suggest that Choiyoi volcanics were exposed at the source area, being the major outcrop to the west of the study area (Fig. 1). Samples of El Relincho Formation show a different source as independently suggested from our compositional analysis on conglomerates. The provenance areas for this section are largely composed of low-grade metamorphic and sedimentary rocks that are widespread within the western Precordillera domain, in addition to volcanic rocks of the Choiyoi Group. Easternmost occurrences of the Choiyoi Group outcrop along the western Precordillera as well (Figs. 1, 2).

\subsection{Paleocurrent analysis}

The main sedimentary structures recorded and measured for the paleocurrent analysis were clast imbrication, flute casts and foresets of crossbeds. Other structures like parting lineation and channel axes were also considered (Fig. 10). Our analysis allows the recognition of two main different paleocurrent directions: toward the east in the Cerro Puntudo Formation and toward the northwest in El Relincho Formation.

The alluvial fan association in the Cerro Puntudo Formation has a mean vector $(\mathrm{Vm})=110.6^{\circ}\left(\sigma=3.4^{\circ} ; \mathrm{Fc}=92.2 \% ; \mathrm{n}=47\right)$. The ephemeral fluvial association has $\mathrm{Vm}=89.2^{\circ}\left(\sigma=2.0^{\circ}\right.$; $\mathrm{Fc}=97.5 \%$; $\mathrm{n}=48)$, including some data in the upper palustrine association. These paleocurrent measurements point to the east direction. On the contrary, the braided fluvial association of El Relincho Formation has a major paleocurrent trend toward the northwest with a $\mathrm{Vm}=316.1^{\circ}$ $\left(\sigma=2.5^{\circ} ; \mathrm{Fc}=94.4 \% ; \mathrm{n}=63\right)$ (Fig. 10).

Provenance analysis based on composition data is consistent with our paleocurrent analysis. The main outcrops of Choiyoi volcanic rocks occur to the west of the study area and paleocurrents toward the east makes them the likely provenance area for the conglomerates of the Cerro Puntudo Formation. On the other hand, outcrops of early Paleozoic low-grade metamorphic and sedimentary rocks located to the southeast are the potential sources for the polymictic conglomerates in the El Relincho Formation, which is consistent with reliable paleocurrent data toward the northwest. A substantial change in the paleocurrent pattern between the Cerro Puntudo Formation and the El Relincho Formation indicates a strong rearrangement of basin drainage to both sides of the unconformity separating these units.

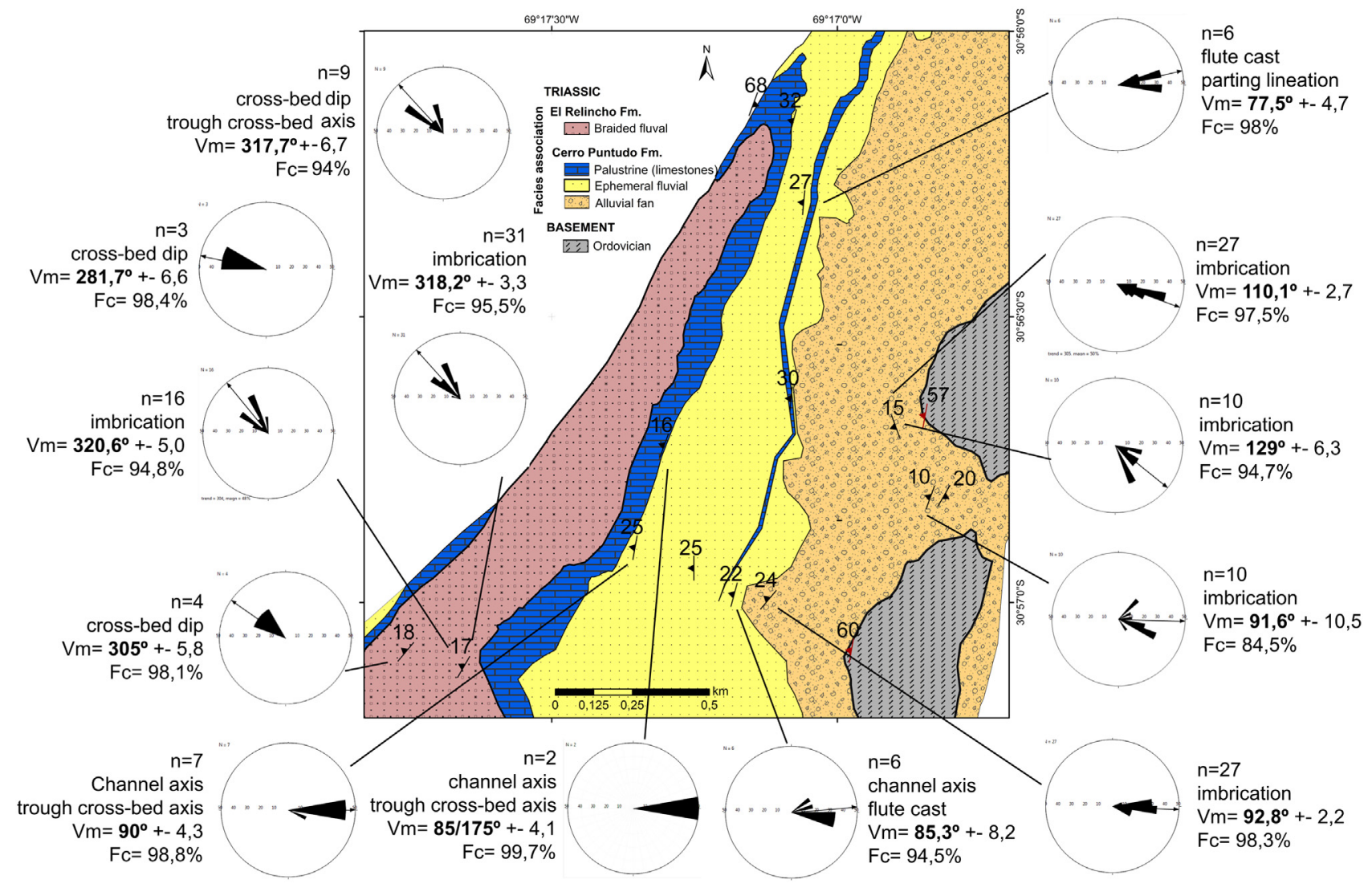

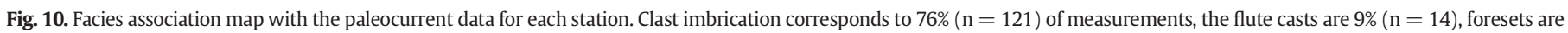
$6 \%(n=9)$ and the other structures correspond to $9 \%(n=15)$, totalizing 159 measurements. 


\section{Discussion}

\subsection{Evolution stages from a source-to-sink perspective}

Rift settings develop different depositional belts associated with basin floor and source area drainages, both from the footwall scarp and the hanging wall ramp (e.g., Leeder and Gawthorpe, 1987). Basin geometry as well as subsidence and sediment delivery exert great influence on transverse tributaries, whereas climate greatly influences active erosion and depositional processes within both catchment and basin (e.g., Smith, 1994). The spatial-temporal relationships between these depositional belts, as well as the first order stratigraphic filling, have been modeled adjusting these variables (e.g., Paola, 2000) and largely considering the distribution of sediments across simple half-graben basins, primarily controlled by activity of the basin master-faults and sediment flux (e.g., Gawthorpe and Leeder, 2000). The stratigraphy of intracontinental rift-basins sufficiently far from coastlines, like in the Cuyo basin, is strongly influenced by changes in discharge regimes, sediment supply, and tectonism (e.g., Blum and Törnqvist, 2000). However, interactions and responses between tectonic and climatic stimulus are not clear when focusing on ancient records, particularly when considering protracted time-intervals where connectivity and drainage integration between separate grabens across transfer zones may greatly modify the filling (Faulds and Varga, 1998; Smith et al., 2013).

Our study helps document changes in the stratigraphic fill, through modifications in the drainage patterns along fossil rift systems, and understand long-term climate changes and connectivity between separate grabens by showing fundamental distinctions between depositional belts influenced by transverse and longitudinal (axial) flux. Considering this approach and according to the data analyzed in the previous sections, the infilling of the Cerro Puntudo depocenter can be separated in three evolutionary stages: isolated synrift, tectonic quiescence and connected synrift. The first two stages belong to the Cerro Puntudo Formation whereas the last stage is represented by the El Relincho Formation.

\subsubsection{Isolated synrift stage}

The fact that coarse-grained alluvial stratigraphy develops within the Cuyo basin onto various substrates reinforces a tectonic trigger and its link to extension (López-Gamundí and Astini, 1992). A fining and thinning upward vertical trend in the lower section of the alluvial fan association of the Cerro Puntudo Formation indicates decreasing surface gradient and consequently, lower accommodation space. The boulder sizes and the dominant gravity processes that operate in this association immediately above the basal unconformity, suggest strong tectonic activity in order to create the available space.

Variable activity in normal faults is compatible with the evolution of fault segments during the initial stage of rifting (Schlische, 1991; Gawthorpe and Leeder, 2000). This has been noted for the Cuyo basin by other authors (Kokogián and Mancilla, 1989; López-Gamundí and Astini, 2004; Barredo and Ramos, 2010). Fault displacement within the Cerro Puntudo area seems to have been important given the thickness and large grain-size recorded in the alluvial fan association. Within the extensional context, alluvial fan deposits are more important close to the border master fault, where topographic gradients are higher due to normal fault activity that in turn controls largely orthogonal paleocurrent patterns. East-directed paleocurrents within the alluvial fan association of the Cerro Puntudo Formation allow us to interpret predominant flow directions toward the hanging wall block located to the east and the master fault and uplifted (footwall) block to the west (Figs. 11, sketch A, 12). The provenance analysis reveals that Choiyoi Group volcanics dominate the footwall. Similar volcanic rocks prevail to the west along the Frontal Cordillera and also outcrop beneath the conglomerates toward the south, where an age of $256.8 \pm 3.5 \mathrm{Ma}$ (Permian/Lopingian) was obtained.

The unidirectional paleocurrent, largely orthogonal, with no axial input and predominance of a unique provenance points to an isolated and closed depocenter (Fig. 12). This is coherent with the initiation of rift systems, when active extension normal fault displacement is prone to generate endorheic basins since tectonic subsidence exceeds sedimentary supply. During such stages, depocenters may remain disconnected and sills may momentarily act as paleogeographic barriers. This condition may help explain the small provenance change and trigger higher aggradation and overfilling rates, due to the absence of external drainage.

Gradually, toward the upper section of the Cerro Puntudo Formation, better organized finer-grained conglomerate deposits reveal a decrease in topographic gradients with no evident climate change as inferred from facies analysis (Fig. 11, sketch B). This would point to decreasing activity along the master fault, allowing depositional system widening, with progressive backstepping and infilling of the faultbounded associated depocenter. Thus, the fining and thinning upward section of the Cerro Puntudo Formation is interpreted as the transition to a more tranquil stage.

\subsubsection{Tectonic quiescence stage}

The uppermost section within the Cerro Puntudo Formation suggests a decreasing accommodation space since it is a thinner section, composed of finer-grained facies with paleosoils and carbonate units, interpreted as shallow lacustrine and palustrine depositional systems. Calcrete profiles within the ephemeral fluvial facies association indicate condensation, decreasing sediment supply and reveal a semi-arid climate for this depositional environment. Isolated channels are interpreted as wadis that preferentially flowed from west to east (Fig. 11, sketch C). Ephemeral fluvial and palustrine associations, including the carbonate section, display little topography, hence development of alternating ephemeral lake and wetland conditions. These characteristics point to decreasing fault-bounded activity, slower accommodation space creation and distinct depositional system associated with tectonically quiescent stages (e.g., Martins-Neto and Catuneanu, 2010) (Fig. 12).

Composition analysis of sandstones in this uppermost section indicates a slightly wider and more varied provenance area, consistent with enlargement of the drainage configuration pattern. Within the depocenter, ponding processes and recurrent water table fluctuation enhance eodiagenetic processes, which indicate closed-basin conditions. This may still point to largely disconnected graben-systems as also indicated by the lenticular geometry of the palustrine deposits at a map scale (see Fig. 2).

A tuff within the ephemeral fluvial association, in the upper section of the Cerro Puntudo Formation, provided a Lower Triassic age of $249.8 \pm 2.5 \mathrm{Ma}$. In the topmost tuffs of this Formation, within the palustrine association, Mancuso et al. (2010) published an age of $243 \pm 1.8 \mathrm{Ma}$ (Middle Triassic). Both ages allow us to infer a minimum of 6.8 Ma for the upper section of the Cerro Puntudo Formation. This estimation reinforces our interpretation of lower accommodation space creation and explains the contrasted facies with the lower section of the Cerro Puntudo Formation. Moreover, limited accommodation space is consistent with limited terrigenous sediment supply prone for development of palustrine depositional systems (Alonso-Zarza and Wright, 2009). Therefore, the upper section of Cerro Puntudo Formation is interpreted as belonging to a tectonic quiescence stage.

\subsubsection{Connected synrift stage}

A distinctive braided fluvial system characterizes the deposition of the El Relincho Formation. This facies association sharply develops overlying the Cerro Puntudo Formation. A prominent unconformity is defined by rugged erosive surface and sudden truncation of the underlying fine-grained mixed carbonate-shale-tuff facies of the previous quiescent stage. Although we have no constraint for the hiatus involved within the unconformity, it should be noted that at map scale, at least $22 \mathrm{~m}$ of section were eroded as shown by the correlation of close stratigraphic sections (700 m distance, Figs. 3, 4). This subtle angularity implies a basin configuration change that, in turn, explains the sudden coarse conglomerates of the El Relincho Formation. The unconformity 


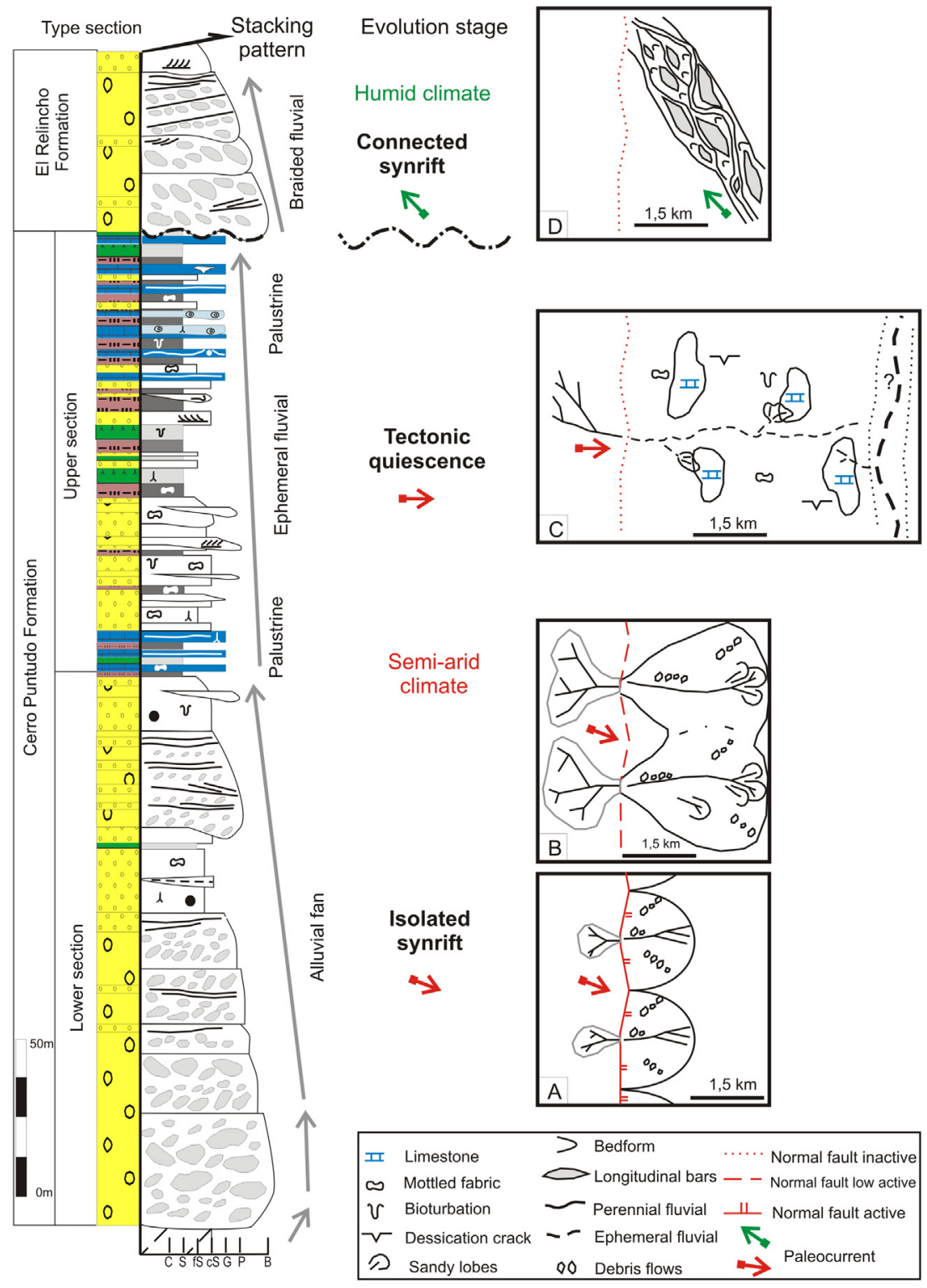

Fig. 11. Summary of the evolution stages and paleogeographic sketches interpreted for Cerro Puntudo deposits.

records not only a drastic change in grain size and paleoenvironments but also a strong change in provenance.

The braided fluvial association of El Relincho Formation has a significant amount of low-grade metamorphic and sedimentary lithics with a paleocurrent direction toward the northwest. This is also in sharp contrast and almost transverse to the underlying pattern in the Cerro Puntudo Formation. This different paleocurrent within the braided fluvial association of El Relincho Formation can be considered an axial direction unrelated to the original master fault that generated the primary accommodation during the deposition of the Cerro Puntudo Formation, hence these data point to a change in sediment supply and in paleoslopes. Therefore, a great geometric change in depositional systems and basin configuration can be inferred (Figs. 11, sketch D, 12).

Changes in geometry, drainage and interconnectivity between separate depocenters along a rift-system may be driven by both tectonic and/or climatic end-members. A climate change may have occurred for the El Relincho Formation because facies analysis suggests a stable fluvial braided system associated with a more humid climate. Although sudden changes in paleocurrents can be related to tectonic activity, unless completely new fault boundaries had become active, paleocurrent patterns might not change drastically. On the other hand, a gradual climate change toward more humid conditions may help to connect previously separated depocenters through axial drainage. This alternative may better explain the strong facies variations and contrasting provenance between the Cerro Puntudo Formation and the El Relincho Formation.

Interactions between axial and transverse drainage may greatly modify architecture of basin filling (Connell et al., 2012). Axial drainages in natural rift settings transport both water and sediment which are related to larger catchments that, in turn, may increase sediment transport capacity. As a result, it is predicted that during the connectivity of separate depocenters, erosional unconformities, like the one separating the Cerro Puntudo Formation and the El Relincho Formation, may be developed before larger accommodation creation takes place.

Because axial drainages collect water and sediment from larger tributary drainages, more polymictic and better sorted conglomerates may occur when compared to transverse-sediment input. Given the better sorting and rounding of the El Relincho Formation conglomerates, we infer a greater distance to the source area. The drainage enlargement configuration within rift basins promotes regional stream 
A - Isolated synrift stage

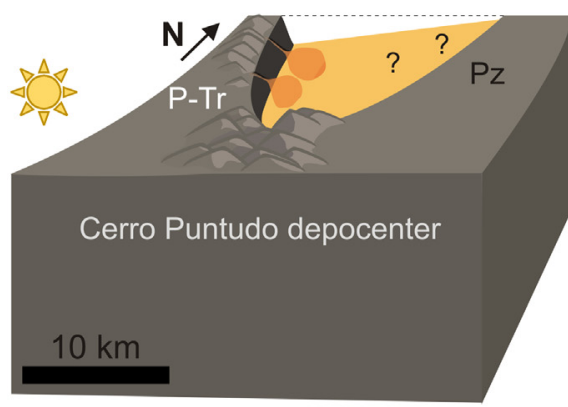

B - Tectonic quiescence stage $\mathrm{N}$

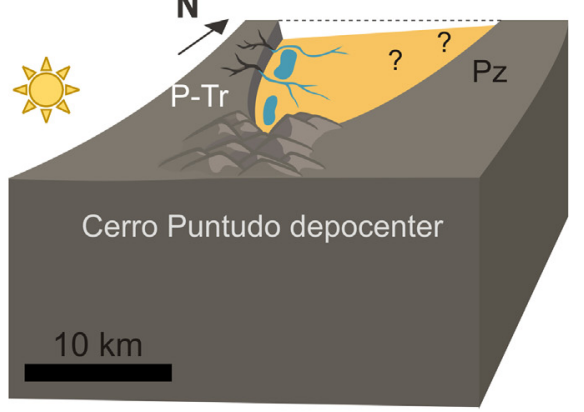

\section{C - Connected synrift stage}

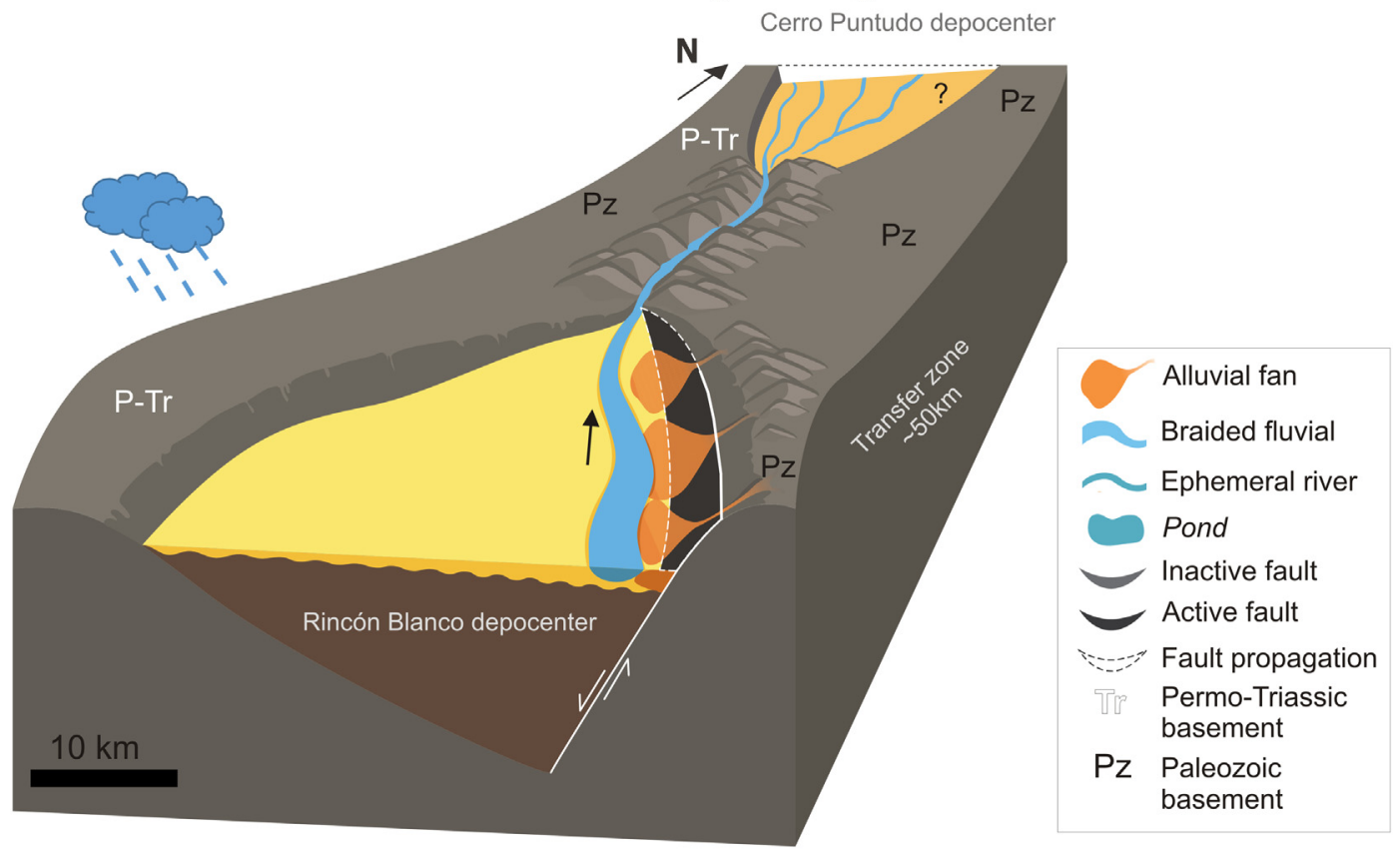

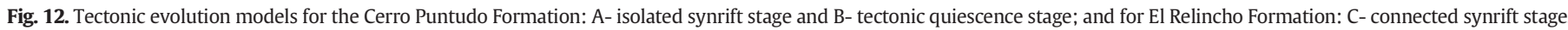

capture that would bring higher perennial sediment/water discharge to the depocenter. This access could be favored by eventual relay ramps, located along border faults or through transfer zones along the rift systems.

As suggested by Connell et al. (2012), bypass of axial loads may occur within internal highs or transfer zones separating depocenters. In these linking areas, subsidence may not accommodate all sedimentation. For this reason, we favor the interpretation that the strong provenance change shown between the Cerro Puntudo Formation and the El Relincho Formation might be better explained by the combination of basin geometry rearrangement and climate change. Both together bear on the reorganization of drainage systems, with major implications for fluvial morphology, spatial distribution of deposition, erosion, sediment budgets and provenance (e.g., Bishop, 1995; Smith et al., 2013).

Numerical modelling of rift systems with opposite depocenter polarities (Smith et al., 2013) shows that drainage connection occurs preferentially along transfer zones. In the less subsiding upstream sub-basin, depocenter connection results in erosion of pre-linking deposits (and of the sill itself), while in the more subsiding downstream sub-basin deposition prevails. This kind of process-response may have operated in the Cuyo basin, and may particularly explain what happened in the Cerro Puntudo sub-basin, with a southeast-northwest connection as revealed by provenance analysis of the El Relincho Formation. According to our data, the Rincón Blanco depocenter, located $50 \mathrm{~km}$ to the south (Fig. 1), would have developed a connection with the Cerro Puntudo graben explaining the strong paleocurrent and compositional change observed above the unconformity.

During the linking process, erosion and incision can take place not only in headwaters adjacent to the main border fault, but in less subsident transfer zones. Although major cobble-boulder populations will tend to deposit in the hanging wall close to the border fault, an important volume of clasts may be exported through axial drainage such as the example of the Fiamignano fault in the Apennines (Whittaker et al., 2010). Considering the Rincón Blanco and the Cerro Puntudo depocenters linked, a regional paleoslope toward the north is suggested, where the Rincón Blanco would be the upstream sub-basin and the Cerro Puntudo, the downstream one (Fig. 12).

The transfer zone between the Rincón Blanco and the Cerro Puntudo depocenters could have been an important source of sediment supply during the linking process, especially if it was a high relief transfer zone (Fig. 12). Connections between other sub-basins within the Cuyo basin could have also occurred. However, as this region was tectonically inverted during Andean shortening, a connection to the Rincón Blanco depocenter is interpreted, since it is presently the closest known depocenter to the south.

The sharp facies and architectural change documented on both sides of the unconformity separating Cerro Puntudo and El Relincho Formations, point to alluvial environments with contrasted transport processes, slopes and sediment/water discharge. These differences may be associated to drainage integration within rift systems. Changes 
from deposition to erosion and back to deposition have been observed elsewhere (Cowie et al., 2006; Fidolini et al., 2013) when separate sub-basins (e.g., isolated grabens) adhering to different base-levels link within rift basins. Thus, a source-to-sink approach may help understand ancient non-marine rift systems, particularly at a regional scale, where extensional basins are segmented into numerous subbasins with different elevations and subsidence rates. The linkage allows direct regional correlations to be made and reveals that significant local unconformities associated to the moment of connection are non-tectonically driven, but influenced by rapid drainage reorganization along the rift system and can particularly develop across transfer zones.

\subsection{Implications in regional Cuyo basin correlation}

In order to verify the hypothesis of connection between the Cerro Puntudo and the Rincón Blanco depocenters within the larger Cuyo basin, a correlation attempt was made based on available geochronological data (Fig. 13) in earlier studies (Ávila et al., 2006; Spalletti et al., 2008; Mancuso et al., 2010; Barredo et al., 2012) and in this study. According to these, the unconformity at the base of the El Relincho Formation in Cerro Puntudo depocenter may be correlated with the angular unconformity of the Panul Formation in Rincón Blanco depocenter. Remarkably, paleocurrent and provenance of the Rincón Blanco facies (Jenchen and Rosenfeld, 2002; Barredo, 2004; Barredo and Ramos, 2010) are consistent with those in the Cerro Puntudo area. Moreover, facies analysis also characterizes a more humid climate for the Panul Formation that ends with the deep-lake deposition of the Carrizalito Formation (Barredo and Ramos, 2010). All these features suggest that both depocenters could have been linked during the development of the unconformity, thus showing similar evolution after connection (Figs. 12, 13).

Climate change toward more humidity seems to be recorded in all depocenters of the Cuyo basin (Kokogián and Mancilla, 1989; Kokogián et al., 1993; Spalletti, 1999; Barredo and Ramos, 2010). Most authors (Kokogián et al., 1993; Barredo and Ramos, 2010; Mancuso et al., 2010; Barredo et al., 2012) interpret an initial synrift stage with low-efficiency alluvial fans, ephemeral fluvial systems and playa-lakes developed in a more arid climate, and a postrift stage (or synrift II) with perennial fluvial systems, deltas and stable lacustrine systems, developed under more humid conditions. Our facies and stacking pattern at the Cerro Puntudo depocenter allow us to suggest that the Cerro Puntudo Formation developed under arid to semi-arid climate, compatible with the early stage synrift. Moreover, recent high-quality U-Pb ages (ca. $243 \mathrm{Ma}$ in Ávila et al., 2006; Mancuso et al., 2010) are consistently showing that the Cerro Puntudo Formation correlates with Río Mendoza and Las Cabras Formations within the better known Cuyo basin stratigraphy, whereas El Relincho Formation records a distinct sedimentation stage under a more humid climate. In the light of the above discussion, previous correlations (Sessarego, 1988; LópezGamundí and Astini, 2004) between palustrine siliciclastic carbonate deposits in the Cerro Puntudo Formation considered a time-equivalent marginal facies belts of the deeper bituminous lake deposits of the Rincón Blanco depocenter (Carrizalito Formation) do not seem suitable.

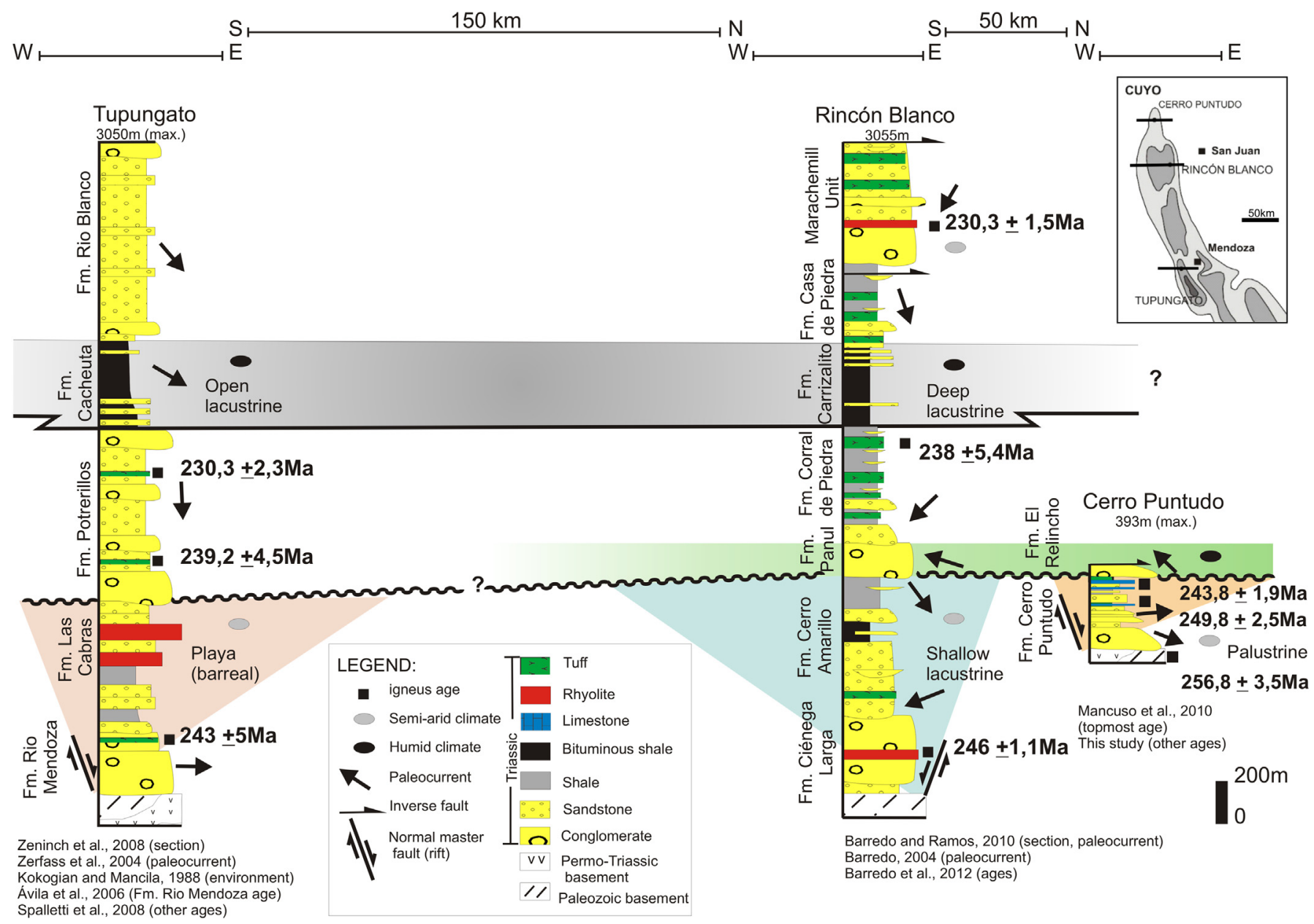

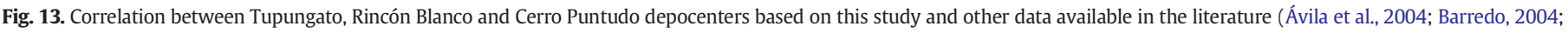

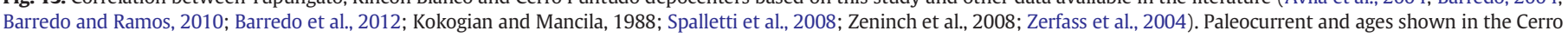
Puntudo lithostratigraphic section are from this study, expect the topmost age. 
Our new correlation suggests that the bituminous shales of the Cuyo basin were not preserved in the Cerro Puntudo area since they should occur up-section of the El Relincho Formation. This implies that in the northernmost Cuyo basin, the potential known source rock is not present.

Based on a source-to-sink approach, this study is an example of how we can relate separate graben stratigraphic fillings within a basin rift evolution. Once the possibility of depocenter linkage is considered, novel correlations between depocenters and alternative interpretations for local unconformities are possible. This approach is suitable for non-marine rift systems, where separate grabens may adhere to different base levels and independent filling rates. Therefore, it may contribute to a better understanding of basin evolution, correlation and its consequences for studies related to natural resources exploration. Although non-marine rift fillings are largely a function of both tectonic rates and climate-driven changes influencing subsidence and accommodation (Holz et al., 2017), source-to-sink modifications implying drainage pattern adjustments can greatly influence the degree of connection between adjacent sub-basins, which can itself influence slope changes, sediment/water discharge variations, transport processes and equilibrium-graded (base level) profiles. These modifications give rise to development of local unconformities between independent riftrelated depocenters that are created by the dynamic linkage of continental rift systems and have not been thoroughly considered in rift sequence stratigraphy models (e.g., Martins-Neto and Catuneanu, 2010; Holz et al., 2017).

Our interpretation on the Cerro Puntudo outcrops differs from previous studies regarding rift geometry (Sessarego, 1988; Stipanicic, 2002; López-Gamundí and Astini, 2004; Barredo and Ramos, 2010). Whereas existing interpretations considered the Cerro Puntudo area as the northern extent of the Rincón Blanco depocenter, with a border master fault system to the east, this study shows that the Cerro Puntudo border fault is located to the west, and thus may justify the development of a separate depocenter for our study area. Barredo (2012) considered the Cerro Puntudo area as a separate graben as well, however, the location of its border fault to the west is a new interpretation that indicates an opposite polarity to the Rincón Blanco depocenter to the south and implies a transfer zone between them. In addition, our interpretation points out that the El Relincho Formation would not be the record of a second synrift stage associated to reactivation of the same border fault, but instead, a product of linked depocenters within the Cuyo basin. One larger-scale implication of this study is that the Cuyo basin rift system with a northwest regional trend (location map in Fig. 1) may have had a much larger extension than shown in usual paleogeographic maps (Stipanicic, 2002), and the Andean contraction was responsible for inversion-extrusion of the Triassic basins that would have continued with a northwest trend into the high cordillera.

\section{Conclusion}

This study helps document strong changes in the stratigraphic fill, through modifications in the drainage patterns along fossil rift systems, and understand long-term climate change and connectivity between separate grabens. These interpretations are based on robust distinctions between depositional belts influenced by flanking tributaries within the lower Cerro Puntudo Formation and predominant axial flux within the upper El Relincho Formation.

An isolated depocenter condition during a closed active synrift stage and tectonic quiescence is deduced from depositional systems, paleocurrent and provenance data. In this context, transverse sediment supply was from a volcanic source area, located in the footwall of normal faults to the west. Afterwards, and above a basin-wide erosive unconformity, a separate stage indicates connection with other grabens. During this connected synrift stage, axial sediment was transported toward the northwest from multiple source areas. This characterizes a linked condition of the Cerro Puntudo depocenter, probably related to the development of an axial drainage network under more humid conditions. Such changes from deposition to erosion and back to deposition may develop when separate sub-basins, adhering to different base-levels, link. This reinforces a source-tosink approach for the study of ancient non-marine rift systems on a regional scale.

The present interpretation of rift evolution during Cerro Puntudo sedimentation differs from previous ones, since the border fault located to the west in the initial rift stage and the generalized slope and supply changes in the El Relincho Formation were not previously described. Therefore, a new correlation scheme between the Cerro Puntudo depocenter and the other depocenters of the Cuyo basin is suggested through the erosive unconformity at the El Relincho Formation, as indicated by facies, paleocurrent and provenance analysis. Below the unconformity, the depocenters developed under similar tectonic-climatic conditions during the initial rift stage. Depocenters appear isolated and facies indicate arid to semi-arid climate. Above the unconformity, depocenters were connected through more integrated drainage patterns that allowed the export of sediments from upstream depocenters to the Cerro Puntudo depocenter and downstream. This basin evolution is compatible with overfilled interconnected grabens developed during a more humid stage.

\section{Acknowledgments}

We are grateful to Petrobras Brazilian Oil Company for supporting this project. We thank Universidad Nácional de Córdoba through funding by the Secretaria de Ciencia y Tecnología. We appreciate the Center for Geosciences Applied to Petroleum Geology (UNESPetro) and the Department of Petrology and Mineralogy at the São Paulo State University (UNESP), the Geochronos Laboratory at the Brasília University and Petrobras Research Center for providing the infrastructure and laboratory facilities. We acknowledge Daniel Boggetti and Agustin Mors for helpful fieldwork assistance. We thank Lucas V. Warren, Roberto S. F. d'Avila, Adali R. Spadini and Dorval C. Dias Filho for discussions on preliminary versions of the manuscript. Dr. Oscar R. López-Gamundí and an anonymous reviewer are thanked for their comments and suggestions that greatly improved this article.

Appendix A. Frequency counting of cobbles (A, B and D) and pebbles (C) in conglomerates. See Fig. 9 for stratigraphic location of the counting stations

\begin{tabular}{|c|c|c|c|c|c|c|c|c|}
\hline Station & Andesite & Rhyolite & Tuff & Agglomerate & Ignimbrite & Green metamorphic & Volcanic breccia & total \\
\hline A & 89 & 6 & 2 & 3 & 0 & 0 & 0 & 100 \\
\hline B & 34 & 43 & 0 & 0 & 4 & 19 & 0 & 100 \\
\hline C & 9 & 44 & 0 & 0 & 0 & 47 & 0 & 100 \\
\hline $\mathrm{D}$ & 13 & 74 & 0 & 0 & 0 & 12 & 1 & 100 \\
\hline
\end{tabular}


Appendix B. Modal composition of 10 sandstone samples (values in percentage) where $Q t=$ total quartz; $F=$ feldspar; $L=$ lithic fragment; Qm = monocrystalline quartz; $\mathbf{Q p}=$ polycrystalline quartz; $\mathbf{L t}=$ total lithic fragment; $\mathbf{L v}=$ volcanic lithic fragment; $\mathbf{L m}=$ metamorphic lithic fragment; $L s=$ sedimentary lithic fragment; $P=$ plagioclase; $K=K$-feldspar; Find = indistinct feldspar. See Fig. 9 for sample location

\begin{tabular}{|c|c|c|c|c|c|c|c|c|c|c|c|c|}
\hline Sample & Qt & $\mathrm{F}$ & $\mathrm{L}$ & $\mathrm{Qm}$ & Qp & $\mathrm{Lt}$ & $\mathrm{Lv}$ & $\mathrm{Lm}$ & Ls & $\mathrm{P}$ & K & Find \\
\hline 36 & 5,7 & 27 & 67,3 & 5,7 & 0 & 67,3 & 67,3 & 0 & 0 & 6,3 & 0,3 & 20,3 \\
\hline 37 & 12,7 & 17,7 & 69,7 & 9,7 & 3 & 72,7 & 69,7 & 0 & 0 & 2,3 & 1,7 & 13,7 \\
\hline $38 b$ & 0 & 27,7 & 72,3 & 0 & 0 & 72,3 & 72,3 & 0 & 0 & 7,7 & 0 & 20 \\
\hline 46 & 9,3 & 25,3 & 65,3 & 9,3 & 0 & 65,3 & 65,3 & 0 & 0 & 5,7 & 1 & 18,7 \\
\hline 03 & 10 & 29,3 & 57 & 8,3 & 1,7 & 58,7 & 56 & 1 & 0 & 2,7 & 5,3 & 21,3 \\
\hline 48 & 11,3 & 47,3 & 41,3 & 7,7 & 3,7 & 45 & 37,3 & 4 & 0 & 3 & 2 & 42,3 \\
\hline 49 & 10,3 & 36,3 & 53,3 & 10,3 & 0 & 53,3 & 49,3 & 4 & 0 & 2,7 & 1,7 & 32 \\
\hline 52 & 27 & 17,3 & 55,7 & 19,3 & 7,7 & 63,3 & 46,3 & 5 & 4,3 & 4,7 & 5,7 & 7 \\
\hline 53 & 33,3 & 32,6 & 34 & 25 & 8,3 & 42,3 & 27,3 & 6,3 & 0,3 & 6,7 & 4,7 & 21,3 \\
\hline 54 & 17 & 42,3 & 40,7 & 15 & 2 & 42,7 & 38 & 2,7 & - & 3,7 & 10 & 28,7 \\
\hline
\end{tabular}

\section{Appendix C. Supplementary data}

Supplementary data associated with this article can be found in the online version, at doi: https://doi.org/10.1016/j.sedgeo.2018.08.007. These data include the Google map of the most important areas described in this article.

\section{References}

Allen, P.A., 2008. From landscapes into geological history. Nature 451, 274-276.

Allen, J.P., Fielding, C.R., 2007. Sequence architecture within a low-accommodation setting: an example of the Permian of the Galilee and Bowen basins, Queensland Australia. American Association of Petroleum Geologists Bulletin 91, 1503-1539.

Allmendinger, R.W., Cardozo, N., Fischer, D., 2012. Structural Geology Algorithms: Vectors and Tensors in Structural Geology. Cambridge University Press.

Alonso-Zarza, A.M., Wright, V.P., 2009. Palustrine carbonates. In: Alonso-Zarza, A.M. Tanner, L. (Eds.), Carbonates in Continental Settings. Facies, Environments and Processes. Developments in Sedimentology 61. Elsevier, Oxford, pp. 103-130.

Ambrosetti, E., Martini, I., Sandrelli, F., 2017. Shoal-water deltas in high-accommodation settings: insights from the lacustrine Valimi Formation (Gulf of Corinth, Greece). Sedimentology 64, 425-452.

Arenas, C., Pinuela, L., García-Ramos, J.C., 2015. Climatic and tectonic controls on carbonate deposition in syn-rift siliciclastic fluvial systems: a case of microbialites and associated facies in the Late Jurassic. Sedimentology 62, 1149-1183.

Argota, M.R., Mors, A., Teixeira, B.M.N., Astini, R.A., 2014. Criterios texturales de actividad biótica y abiótica en carbonatos terrestres triásicos. XIV Argentine Sedimentological Meeting, Puerto Madryn, pp. 24-25 (in Spanish).

Armitage, J.J., Duller, R.A., Whittaker, A.C., Allen, P.A., 2011. Transformation of tectonic and climatic signals from source to sedimentary archive. Nature Geoscience 4 231-235.

Astini, R.A., Thomas, W.A., 1999. Origin and evolution of the Precordillera terrane of western Argentina; a drifted Laurentian orphan. In: Ramos, V.A., Keppie, D. (Eds.), Laurentia-Gondwana Connections before Pangea. Geological Society of America, Special Paper 336, pp. 1-20.

Ávila, J.N., Chemale, J., Mallmann, G., Kawashita, K., Armstrong, R.A., 2006. Combined stratigraphic and isotopic studies of Triassic strata, Cuyo Basin, Argentine Precordillera. Geological Society of America Bulletin 118, 1088-1098.

Barredo, S.P., 2004. Análisis estructural y tectosedimentario de la subcuenca de Rincón Blanco, Precordillera Occidental, Provincia de San Juan. (Ph.D. thesis). Universidad de Buenos Aires, Buenos Aires, Argentina (325 pp., in Spanish).

Barredo, S.P., 2012. Geodynamic and tectonostratigrafic study of a continental rift: the Triassic Cuyana Basin, Argentina. In: Sharkov, E.V. (Ed.), Tectonics - Recent Advances. Intech, pp. 1-32.

Barredo, S., Ramos, V.A., 2010. Caracteristicas tectonicas y tectosedimentarias del hemigraben Rincon Blanco, cuenca Cuyana: Una sintesis. Revista de la Asociación Geológica Argentina 66, 133-145 (in Spanish).

Barredo, S., Chemale, F., Marsicano, C., Ávila, J.N., Ottone, E.G., Ramos, V.A., 2012. Tectonosequence stratigraphy and U-Pb zircon ages of the Rincón Blanco Depocenter, northern Cuyo Rift, Argentina. Gondwana Research 21, 624-636.

Benavente, C.A., Mancuso, A.C., Cabaleri, N.G., 2012. First occurrence of charophyte algae from a Triassic paleolake in Argentina and their paleoenvironmental context. Palaeogeography, Palaeoclimatology, Palaeoecology 363-364, 172-183.

Benavente, C., Mancuso, A., Cabaleri, N., Gierlowski-Kordesch, E., 2015. Comparison of lacustrine successions and their palaeohydrological implications in two sub-basins of the Triassic Cuyana rift, Argentina. Sedimentology 62, 1771-1813.

Bishop, P., 1995. Drainage rearrangement by river capture, beheading and diversion. Progress in Physical Geography 19, 449-473.

Blum, M.D., Törnqvist, T.E., 2000. Fluvial responses to climate and sea-level change; a review and look forward. Sedimentology 47, 2-48.
Bühn, B., Pimentel, M.M., Matteini, M., Dantas, E.L., 2009. High spatial resolution analysis of $\mathrm{Pb}$ and $\mathrm{U}$ isotopes for geochronology by laser ablation multi-collector inductively coupled plasma mass spectrometry (LA-MC-ICP-MS). Annals of the Brazilian Academy of Sciences 81, 99-105.

Cardó, R., Dias, I.N., 2005. Memoria Folha Geológica 3169-I, Rodeo. Servicio Geológico Minero Argentino, Buenos Aires (52 pp., in Spanish).

Cardozo, N., Allmendinger, R.W., 2013. Spherical projections with OSXStereonet. Computers \& Geosciences 51, 193-205.

Charrier, R. Pinto, L., Rodríguez, M.P. 2007. Tectonostratigraphic evolution of the Andean Orogen in Chile. In: Moreno, T., Gibbons, W. (Eds.), The Andes of Chile. Geological Society of London, pp. 21-114.

Connell, S.D., Wonsuck, K., Smith, G.A., Paola, C., 2012. Stratigraphic architecture of an experimental basin with interacting drainages. Journal of Sedimentary Research 82, $326-344$

Cowie, P., Attal, M., Tucker, G., Whittaker, A., Naylor, M., Ganas, A., Roberts, G., 2006. Investigating the surface process response to fault interaction and linkage using a numerical modelling approach. Basin Research 18, 231-266.

Criado Roqué, P., Mombrú, C.A., Ramos, V.A., 1981. Estructura e interpretación tectónica: Geología y recursos naturales de la Provincia de San Luis. VII Congreso Argentino, Buenos Aires, pp. 155-192 (in Spanish).

Dickinson, W.R., 1970. Interpreting detrital modes of graywacke and arkose. Journal of Sedimentary Petrology 40, 695-707.

Dickinson, W.R., 1985. Interpreting provenance relations from detrital modes of sandstones. In: Zuffa, G.G. (Ed.), Provenance of Arenites. D. Reidel Publishing Company, pp. 333-361.

Dickinson, W.R., 2008. Conglomerate clast counts in Oligocene-Miocene strata north from the Catalina Core Complex to the Gila River Valley, southeastern Arizona. Arizona Geological Survey Contributed Report 1-28.

Esteban, M., Klappa, C., 1983. Subaerial exposure environment. In: Scholle, P.A., Bebout, D.G., Moore, C.H. (Eds.), Carbonate Depositional Environments. American Association of Petroleum Geologists, Memoir 33, pp. 1-96.

Faulds, J.E., Varga, R.J., 1998. The role of accommodation zones and transfer zones in the regional segmentation of extended terranes. In: Faulds, J.E., Stewart, J.H. (Eds.), Accommodation Zones and Transfer Zones: The Regional Segmentation of the Basin and Range Province. Geological Society of America, Special Paper 323, pp. 1-45.

Fidolini, F., Ghinassi, M., Aldinucci, M., Billi, P., Boaga, J., Deiana, R., Brivio, L., 2013. Faultsourced alluvial fans and their interaction with axial fluvial drainage: an example from the Plio-Pleistocene Upper Valdarno Basin (Tuscany, Italy). Sedimentary Geology $289,19-39$

Gawthorpe, R.L, Leeder, M.R., 2000. Tectono-sedimentary evolution of active extensional basins. Basin Research 12, 195-218.

Gazzi, P., 1966. Le arenarie del flysh sopracretaceo del'Appennino modenese: correlazioni con il flysch di Monghidoro. Mineralogica et Petrografica Acta 12, 69-97 (in Italian).

Giambiagi, L., Mescua, J., Bechis, F., Martinez, A., Folguera, A., 2011. Pre-Andean deformation of the Precordillera southern sector, southern Central Andes. Geosphere 7 , 219-239.

Gierlowski-Kordesch, E.H., 2010. Lacustrine carbonates. In: Alonso-Zarza, A.M., Tanner, L. (Eds.), Carbonates in Continental Settings. Facies, Environments and Processes. Developments in Sedimentology 61. Elsevier, Oxford, pp. 1-102.

Holz, M., Vilas-Boas, D.B., Troccoli, E.B., Santana, V.C., Vidigal-Souza, P.A., 2017. Conceptual models for sequence stratigraphy of continental rift successions. In: Montenari, $\mathrm{M}$. (Ed.)Advances in Sequence Stratigraphy. Stratigraphy \& Timescales 2, pp. 119-186.

Jenchen, U., Rosenfeld, U., 2002. Continental Triassic in Argentina: response to tectonic activity. Journal of South America Earth Sciences 15, 461-479.

Jervey, M.T. Van Wagoner, J.C. 1988. Quantitative geological modeling of siliciclastic rock sequences and their seismic expression. In: Wilgus, C.K., Hastings, B.S., Kendall, C.G.St.C., Posamentier, H.W., Ross, C.A. (Eds.), Sea-Level Changes - An Integrated Approach. Society of Economic Paleontologists and Mineralogists, Special Publication 42, pp. 47-69.

Kokogián, D.A., Mancilla, O., 1989. Analisis estratigrafico secuencial de la cuenca Cuyana. In: Chelbi, G., Spalletti, L. (Eds.), Cunencas Sedimentarias Argentinas. Tucumán: Serie Correlación Geologíca 6, pp. 169-201 (in Spanish). 
Kokogián, D., Fernandez Seveso, F., Mosquera, A., 1993. Las secuencias sedimentarias triásicas. XII Congreso Geológico Argentino e II Congreso de Exploración de Hidrocarburos. Relatorio Geología y Recursos Naturales de Mendoza 1, pp. 65-78 (in Spanish).

Kosler, J., Fonneland, H., Sylvester, P., Tubrett, M., Pedersen, R.B., 2002. U-Pb dating of detrital zircons for sediment provenance studies - a comparison of laser ablation ICMPS and SIMS techniques. Chemical Geology 182, 605-618.

Krapovickas, V., Mángano, M.G., Mancuso, A.C., Marsicano, C.A., Volkheimer, W., 2008. Icnofaunas triásicas en abanicos aluviales distales: evidencias de la Formación Cerro Puntudo, Cuenca Cuyana, Argentina. Ameghiniana 45, 463-472 (in Spanish).

Lambiase, J.J., Morley, C.K., 1999. Hydrocarbons in rift basins: the role of stratigraphy. Philosophical Transactions of the Royal Society A - Mathematical Physical and Engineering Sciences 357, 877-900.

Leeder, M.R., Gawthorpe, R.L., 1987. Sedimentary models for extensional tilt-block/halfgraben basins. In: Coward, M.P., Dewey, J.F., Hancock, P.L. (Eds.), Continental Extension Tectonics. Geological Society of London, Special Publication 28, pp. 139-152.

López-Gamundí, O., Astini, R.A., 1992. Caracterización de facies lacustres en la sección basal del Triássico de El Alcázar. Fourth Argentine Sedimentological Meeting, Agua de Los Pajaritos, Argentina, pp. 97-104 (in Spanish).

López-Gamundí, O., Astini, R.A., 2004. Alluvial fan-lacustrine association in the fault tip end of a half-graben, northern Triassic Cuyo basin, western Argentina. Journal of South America Earth Sciences 17, 253-265.

Ludwig, K.R., 2003. Isoplot 3.00: A Geochronological Toolkit for Microsoft Excel. Berkeley Geochronological Center, Special Publication 4 (70 pp.).

Mancuso, A.C., 2009. Taphonomic analysis in lacustrine environment: two very different Triassic lake paleoflora contexts from Western Gondwana. Sedimentary Geology 222, 149-159.

Mancuso, A.C., Chemale, F., Barredo, S., Ávila, J.N., Ottone, E.G., Marsicano, C., 2010. Age constraints for the northernmost outcrops of the Triassic Cuyana Basin, Argentina. Journal of South America Earth Sciences 30, 97-103.

Martins-Neto, M.A., Catuneanu, O., 2010. Rift sequence stratigraphy. Marine and Petroleum Geology 27, 247-253.

Miall, A.D., 1977. A review of the braided river depositional environment. Earth-Science Reviews 13, 1-62.

Miall, A.D., 1996. The Geology of Fluvial Deposits - Sedimentary Facies, Basin Analysis, and Petroleum Geology. Springer-Verlag, New York (582 pp.).

Mombrú, C.A., 1974. Observaciones geológicas en el Valle de Calingasta-Tocota. Provincia de San Juan. Unpublished Report. YPF (Yacimientos Petrolíferos Fiscales), Buenos Aires (in Spanish).

Mpodozis, C., Kay, S.M., 1992. Late Paleozoic to Triassic evolution of the Gondwana margin: evidence from Chilean Frontal cordilleran batholiths $\left(28^{\circ} \mathrm{S}\right.$ to $\left.31^{\circ} \mathrm{S}\right)$. Geological Society of America Bulletin 104, 999-1014.

Muto, T., Steelb, R., 2000. The accommodation concept in sequence stratigraphy: some dimensional problems and possible redefinition. Sedimentary Geology 130, 1-10.

Nemec, W., Steel, R.J., 1984. Alluvial and coastal conglomerates: their significant features and some comments on gravelly mass-flow deposits. In: Koster, E.H., Steel, R.J. (Eds.), Sedimentology of Gravels and Conglomerates. Canadian Society of Petroleum Geologists, pp. 1-31.

Nichols, G.J., Fisher, J.A., 2007. Processes, facies and architecture of fluvial distributary system deposits. Sedimentary Geology 195, 75-90.

Paola, C., 2000. Quantitative models of sedimentary basin filling. Sedimentology 47, 121-178.

Pettijohn, F.J., 1975. Sedimentary Rocks. Third ed. Harper and Row, New York (628 pp.).

Platt, N.H., Wright, V.P., 1992. Palustrine carbonates and the Florida Everglades: toward an exposure index for the fresh-water environment. Journal of Sedimentary Research 6, 1058-1071.
Potter, P.E., Pettijohn, F.J., 1977. Paleocurrents and Basin analysis. Second ed. SpringerVerlag, New York (425 pp.).

Ramos, V.A., 1994. Terranes of Southern Gondwanaland and their control in the Andean structure $\left(30^{\circ} 33^{\circ} \mathrm{S}\right.$ Latitude). In: Reutter, K.J., Scheuber, E., Wigger, P.J. (Eds.), Tectonics of the Southern Central Andes. Structure and Evolution of an Active Continental Margin. Springer-Verlag, Berlin, pp. 249-261.

Ramos, V.A., Kay, S.M., 1991. Triassic rifting and associated basalts in the Cuyo basin, central Argentina. In: Harmon, R.S., Rapela, C.W. (Eds.), Andean Magmatism and Its Tectonic Setting. Geological Society of America Special Paper 265, pp. 79-92.

Riding, R., 2000. Microbial carbonates: the geological record of calcified bacterial-algal mats and biofilms. Sedimentology 47, 179-214.

Schlische, R.W., 1991. Half-graben basin filling models: new constraints on continental extensional basin development. Basin Research 3, 123-141.

Sessarego, H.L.F., 1988. Estratigrafía de las secuencias epiclásticas devónicas a triásicas aflorantes al norte del río San Juan y al oeste de la sierra del Tigre, provincia de San Juan. (Ph.D.thesis). Universidad de Buenos Aires, Buenos Aires, Argentina (324 pp., in Spanish).

Smith, G.A., 1994. Climatic influences on continental deposition during late-stage filling of an extensional basin, southeastern Arizona. Geological Society of America Bulletin 106, 1212-1228.

Smith, J., Finch, E., Brocklehurst, S.H., Gawthorpe, R.L., 2013. Regional source-to-sink systems within intra-continental rifts: the importance of fluvial connectivity and drainage integration. American Association of Petroleum Geologists, Annual Convention and Exhibition, Pittsburgh, Pennsylvania, Search and Discovery (Article \#41151).

Spalletti, L.A., 1999. Cuencas triásicas del oeste argentino: origen y evolución. Acta Geologica Hispánica 32, 29-50 (in Spanish).

Spalletti, L.A., Fanning, C.M., Rapela, C.W., 2008. Dating the Triassic continental rift in the southern Andes: the Potrerillos Formation, Cuyo Basin, Argentina. Geologica Acta 6 267-283 (in Spanish)

Stipanicic, P.N., 2002. El Triásico en la Argentina. In: Stipanicic, P.N., Marsicano, C.A. (Eds.) Léxico Estratigráfico de La Argentina. Associación Geológica Argentina 26, pp. 1-24 (in Spanish).

Strelkov, E., Alvarez, L., 1984. Análisis estratigráfico y evolutivo de la cuenca triásica mendocina-sanjuanina. IX Congreso Geológico Argentino 3, pp. 115-130 (in Spanish).

Teixeira, B.M.N., 2016. Evolução sedimentar da seção siliciclástica-carbonática triássica na porção norte da Bacia Cuyo, oeste da Argentina. (M.Sc. thesis). Universidade Estadual Paulista, Rio Claro, Brazil (207 pp, in Portuguese).

Uliana, M.A., Biddle, K., 1988. Mesozoic-Cenozoic paleogeographic and geodynamic evolution of southern South America. Revista Brasileira de Geociencias 18, 172-190.

Verrecchia, E.P., 2007. Lacustrine and palustrine geochemical sediments. In: Nash, D.J., McLaren, S.J. (Eds.), Geochemical Sediments and Landscapes. Blackwell Publishing Ltd., Oxford, pp. 298-329.

Whittaker, A.C. Attal, M. Allen, P.A. 2010. Characterising the origin, nature and fate of sediment exported from catchments perturbed by active tectonics. Basin Research 22, 809-828.

Zencich, S., Villar, H., Boggetti, D., 2008. Sistema petrolero Cacheuta-Barrancas de la cuenca Cuyana, provincia de Mendoza, Argentina. In: Cruz, C.E., Rodríguez, J.F., Henchem, J.J., Villar, H.J. (Eds.), Sistemas Petroleros de las Cuencas Andinas. Instituto Argentino del Petróleo y del Gas, pp. 109-134 (in Spanish).

Zerfass, H., Chemale Jr., F., Schultz, C.L., Lavina, E., 2004. Tectonics and sedimentation in southern South America during Triassic. Sedimentary Geology 166, 265-292. 